Article

\title{
Spatiotemporal Patterns of Crop Irrigation Water Requirements in the Heihe River Basin, China
}

\author{
Yaqun Liu ${ }^{1,2}$ (1) , Wei Song ${ }^{1, *}$ (1) and Xiangzheng Deng ${ }^{1,3}$ \\ 1 Key Laboratory of Land Surface Pattern and Simulation, Institute of Geographic Sciences and Natural \\ Resources Research, Chinese Academy of Sciences, Beijing 100101, China; yaqun_liu@163.com (Y.L.); \\ dengxz.ccap@igsnrr.ac.cn (X.D.) \\ 2 University of Chinese Academy of Sciences, No. 19(A), Yuquan Road, Shijingshan District, \\ Beijing 100049, China \\ 3 Center for Chinese Agricultural Policy, Chinese Academy of Sciences, Beijing 100101, China \\ * Correspondence: songw@igsnrr.ac.cn; Tel.: +86-10-6488-9450
}

Received: 30 June 2017; Accepted: 15 August 2017; Published: 17 August 2017

\begin{abstract}
Agricultural expansion, population growth, rapid urbanization, and climate change have all significantly impacted global water supply and demand and have led to a number of negative consequences including ecological degradation and decreases in biodiversity, especially in arid and semi-arid areas. The agricultural sector consumes the most water globally; crop irrigation alone uses up more than $80 \%$ of available agricultural water. Thus, to maintain sustainable development of the global economy and ecosystems, it is crucial to effectively manage crop irrigation water. We focus on the arid and semi-arid Heihe River Basin (HRB), China, as a case study in this paper, extracting spatiotemporal information on the distribution of crop planting using multi-temporal Thematic Mapper and Enhanced Thematic Mapper Plus (TM/ETM+) remote sensing (RS) images. We estimate the spatiotemporal crop irrigation water requirements $\left(I W R_{c}\right)$ using the Food and Agriculture Organization of the United Nations (FAO) Penman-Monteith method and reveal variations in $I W R_{c}$. We also analyze the impact of changes in crop planting structure on $I W R_{c}$ and discuss strategies for the rational allocation of irrigation water as well as policies to alleviate imbalance between water supply and demand. The results of this study show that effective rainfall (ER) decreases upstream-to-downstream within the HRB, while crop evapotranspiration under standard conditions $\left(E T_{c}\right)$ increases, leading to increasing spatial variation in $I W R_{c}$ from zero up to $150 \mathrm{~mm}$ and between 300 and $450 \mathrm{~mm}$. Data show that between 2007 and 2012, annual mean ER decreased from 139.49 to $106.29 \mathrm{~mm}$, while annual mean $E T_{c}$ increased from 483.87 to $500.38 \mathrm{~mm}$, and annual mean $I W R_{c}$ increased from 339.95 to $370.11 \mathrm{~mm}$. Data show that monthly mean $I W R_{c}$ initially increased before decreasing in concert with crop growth. The largest values for this index were recorded during the month of June; results show that $I W R_{c}$ for May and June decreased by 8.14 and $11.67 \mathrm{~mm}$, respectively, while values for July increased by $5.75 \mathrm{~mm}$ between 2007 and 2012. These variations have helped to ease the temporal imbalance between water supply and demand. Mean $I W R_{c}$ values for oilseed rape, corn, barley, and other crops all increased over the study period, from 208.43, 349.35, 229.26, and $352.85 \mathrm{~mm}$, respectively, in 2007, to $241.81,393.10,251.17$, and $378.86 \mathrm{~mm}$, respectively, in 2012 . At the same time, the mean $I W R_{c}$ of wheat decreased from $281.53 \mathrm{~mm}$ in 2007 to $266.69 \mathrm{~mm}$ in 2012. Mainly because of changes in planting structure, the total $I W R_{c}$ for the HRB in 2012 reached $2692.58 \times 10^{6} \mathrm{~m}^{3}$, an increase of $332.16 \times 10^{6} \mathrm{~m}^{3}(14.07 \%)$ compared to 2007 . Data show that $23.11 \%\left(76.77 \times 10^{6} \mathrm{~m}^{3}\right)$ of this increase is due to crop transfers, while the remaining $76.89 \%\left(255.39 \times 10^{6} \mathrm{~m}^{3}\right)$ is the result of the rapid expansion of cultivated land. Thus, to maintain both the sustainable development and ecological security of the HRB, it is crucial to efficiently manage and utilize agricultural water in light of spatiotemporal patterns in $I W R_{c}$ changes as well as $I W R_{c}$ variations between different crops. The cultivation of water-demanding crops and the further expansion of agricultural land should also be avoided.
\end{abstract}


Keywords: crop irrigation water requirements; crop planting structure; evapotranspiration; TM/ETM+ RS images; FAO Penman-Monteith method; multi-temporal NDVWI; Heihe River Basin

\section{Introduction}

Water is the most ubiquitous and active substance on Earth, intimately involved in the formation and evolution of all facets of the environment, including biogeochemical cycles, climate change, and the configuration of the planet [1,2]. Water is critical to the survival of biological organisms and ecosystems, and thus to sustainable development, especially food security [3,4]. In light of the comprehensive effects of various factors, including the natural environment, social economy, and technology, more than 40 countries worldwide (about $40 \%$ of the global population) currently face critical water shortages, severely restricting their sustainable social and ecological development $[1,5,6]$. Imbalances in water supply and demand lead to shortages; specifically, global climate change, population growth, rapid urbanization, and agricultural expansion have all caused the water demands of different sectors to increase rapidly [7-11]. Global warming leads to increased evapotranspiration, which aggravates water cycling processes and causes increased rainfall [12-15]. However, in most arid regions where water is scarce, rainfall is decreasing, leading to an increasing imbalance between global water supply and demand [16-19]. At the same time, wastewater and pollution exacerbate water shortages and cause a number of negative effects including ecosystem degradation and decreases in biodiversity [20-23]. It is therefore critical to understand the water supply available to, and the demand of, the main water-using sectors as well as to explore reasonable and sustainable ways to utilize this resource to ensure regional sustainable development and ecological security.

Research on the supply of water has mainly focused on total and available volumes. A range of climate and hydrological models, including the Soil and Water Assessment Tool (SWAT), the Global Hydrologic Evaluation Model (GHEM), the Regional Hydro-climate Model (Reg-HCM), the Rainfall-Runoff Modeling System (PRMS), and the Water Balance/Transport Model (WBM/WTM), have all been used to quantitatively estimate rainfall and runoff at different scales, including globally, nationally, and at the level of individual basins [24-27]. In contrast, research on water demand has mainly focuses on the usage of different sectors such as agricultural, urban domestic and ecological. In this context, water demand is usually estimated based on factors such as population size, cultivated and ecological land area, and water use efficiency [1,2,28,29]. Amongst the different user sectors, agriculture consumes the highest volumes of water globally; irrigation water, for example, accounts for more than $80 \%$ of total worldwide agricultural consumption. Thus, research to date has estimated crop irrigation water requirement $\left(I W R_{c}\right)$ based mainly on models such as CROPWAT, AquaCrop, and PolyCrop [30-34]. These approaches, however, are unable to evaluate spatiotemporal patterns in $I W R_{c}$ at high spatial resolution and thus cannot be used to determine differences over time and space and due to crop types. This lack of spatiotemporal data on $I W R_{c}$ for different crop types has hampered the scientific research that underlies comprehensive water management.

Compared with developed countries, water shortages in developing regions globally are more acute and less well-studied, especially in arid and semi-arid regions. China is one of the largest developing countries and one of the most arid; $20 \%$ of the global population live in this country yet it boasts between just $5 \%$ and $7 \%$ of global freshwater resources. The available water per capita in China is just a quarter of the global mean [35,36]. Arid and semi-arid regions in Northwest China make up $30 \%$ of the national land area, but have less than $20 \%$ of total national available water resources because rainfall is low and evapotranspiration is high; thus, water shortages in this region are of particular concern [1,9]. This issue is even more critical because much of the irrigated cultivated land in China is also distributed in these arid and semi-arid areas; natural rainfall cannot meet the water requirements of crops in this region and so supplementary irrigation is essential to increase yields and to guarantee food security in these areas $[15,37,38]$. Agricultural irrigation water nationally accounts 
for $60 \%$ of total water use, but more than $80 \%$ of total consumption in the arid and semi-arid areas of Northwest China [2,25]. Thus, accurate $I W R_{c}$ calculations are crucial to the regional social-economic and ecological sustainable development of these areas where water is scarce [37,39].

The rapid expansion of agricultural oases combined with population growth and urbanization have further exacerbated the imbalance between urban and agricultural water use in China [28]. Thus, to meet escalating water demands for crop irrigation, agricultural producers have utilized increasing volumes of runoff and groundwater which leads to ecosystem degradation including the seasonal cutoff of rivers, groundwater overdraft, and decreasing ecological land area [1,40,41]. To mitigate these issues, the Chinese government has implemented a range of water management measures concerning water yield, water rights, and water prices and has also promoted the application of new technologies including drip and sprinkler irrigation [28,42,43]. However, managers and producers are still unable to effectively allocate irrigation water according to actual demand because of the absence of high-precision, fine-scale spatiotemporal $I W R_{c}$ data. This situation has led to inefficient water use including irrigation waste and deficits [28]. It is therefore critically important to provide comprehensive data on water usage as it relates to the spatiotemporal distribution of crops, climate, and evapotranspiration in order to precisely estimate $I W R_{c}$. Such data will support decision making, enable the formulation of efficient irrigation schemes, and allow the implementation of comprehensive water management measures to alleviate the negative economic and ecological effects caused by shortages.

Water shortages are restricting the sustainable development of society, the economy, and ecosystems within the Heihe River Basin (HRB), a continental system that encompasses both arid and semi-arid regions of China. The rapid expansion of agricultural oases in recent decades, as well as expansion and changes to crop planting structures, have led to rapidly increasing demands for agricultural water in the HRB [44-46]. At the same time, however, the water supply of this region has not kept pace with demand, even though it has increased slowly and intermittently as climate has become warmer and wetter. Rapid population growth and urbanization has further exacerbated the water supply and demand imbalance between agriculture, cities, and ecology and has led to negative effects, including ecological degradation. Understanding changes in spatiotemporal $I W R_{c}$ patterns because of changes in crop planting structures is therefore critical to the comprehensive management of water resources. Thus, using the HRB as our study area, we extracted spatiotemporal distributional information on crop planting structures using multi-temporal Thematic Mapper and Enhanced Thematic Mapper Plus (TM/ETM+) remote sensing (RS) images and calculated spatiotemporal $I W R_{c}$ using the Food and Agriculture Organization of the United Nations (FAO) Penman-Monteith formula. The objectives of this study are: (1) To reveal the spatiotemporal characteristics of variation in effective rainfall (ER), crop evapotranspiration, and $I W R_{c}$ between 2007 and 2012 in the HRB; (2) To analyze the influences of crop planting structure changes on $I W R_{c}$; (3) To understand the reasons underlying spatiotemporal variation in $I W R_{c}$; and (4) To discuss the implementation of policies that could contribute to alleviating the imbalance between agricultural water supply and demand.

\section{Research Area and Data Sources}

\subsection{Research Area}

The HRB is the second largest continental river basin within the arid and semi-arid areas of Northwest China, located in the center of the "One Belt And One Road" and "Silk Roads" economic belts $\left(97^{\circ} 30^{\prime} \mathrm{E}-101^{\circ} 43^{\prime} \mathrm{E}, 37^{\circ} 55^{\prime} \mathrm{N}-40^{\circ} 00^{\prime} \mathrm{N}\right)$ (Figure 1). The HRB borders the Qinghai-Tibet Plateau in the southwest, the Shule River Basin in the west, the Shiyang River Basin in the east, and Mongolia in the north. The entire basin encompasses an area of $12.80 \times 10^{6}$ ha and consists of 11 administrative counties. The upper, middle, and lower reaches of the HRB are demarcated by the Yingluo and Zhengyi gorges; the upper reaches of this system mainly comprise the Qilian Mountain (Qilian and Sunan counties) water conservation area, while the middle reaches encompass agricultural oases in the center of the Hexi Corridor (i.e., Shandan, Minle, Ganzhou, Linze, Gaotai, Suzhou, and Jiayuguan 
counties), and the lower reaches extend into the Gobi Desert (Jinta and Egina counties). The HRB is located in the central part of the Eurasian plate, and is characterized by a temperate continental climate. This region is typically dry and water is scarce; the small amount of rainfall seen within the HRB tends to have a non-uniform spatiotemporal distribution. Mean annual rainfall in the upper, middle, and lower reaches of the HRB decreases gradually, from 250-500 mm, 100-250 mm, and less than $50 \mathrm{~mm}$, respectively; $70 \%$ of the rainfall are concentrated in June, July, and August, with an annual potential evapotranspiration of 2400-3000 mm.

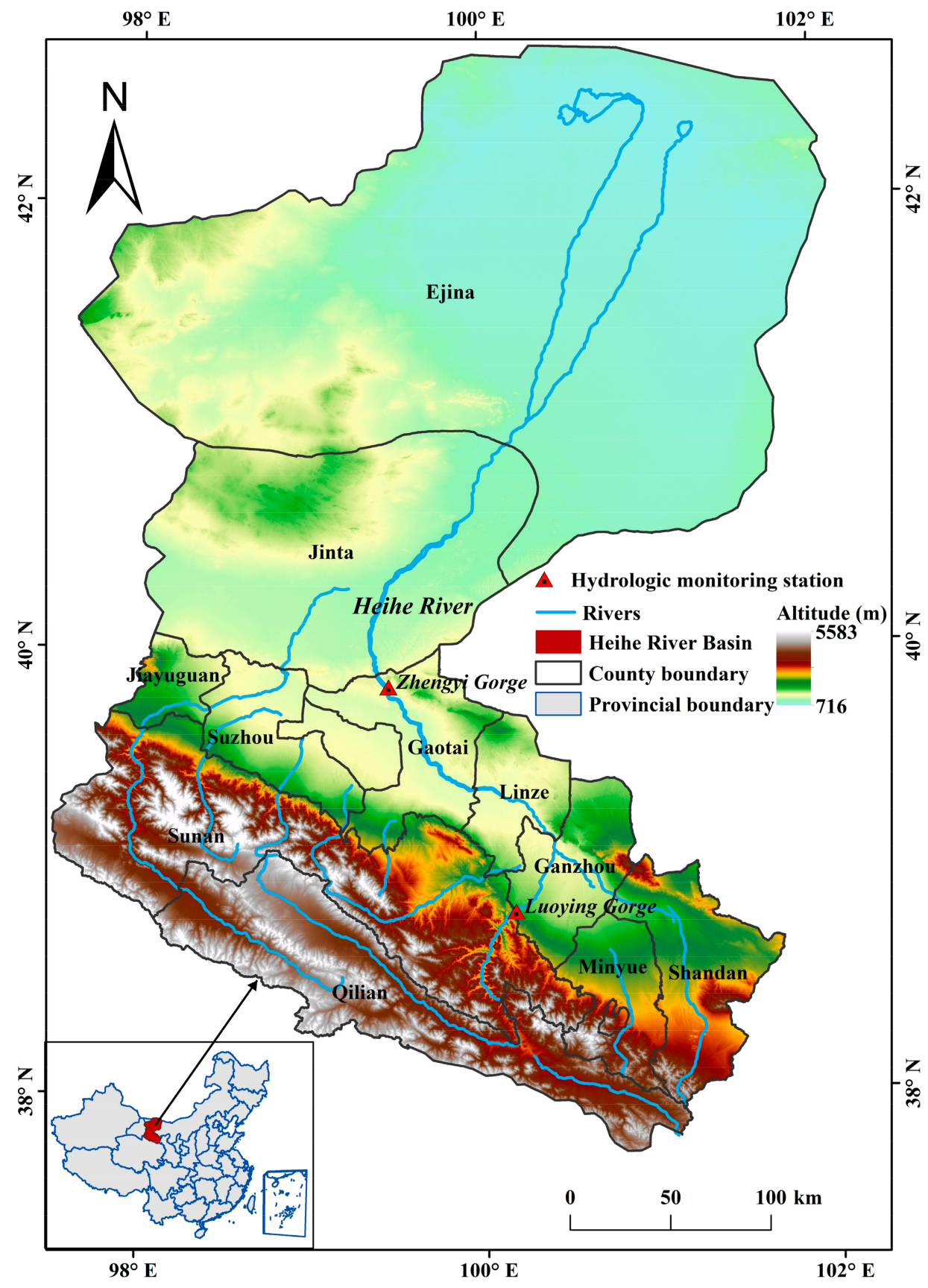

Figure 1. Map to show the geographical location and administrative divisions of the HRB.

Water resources are the most important factor for ecosystem maintenance and the social and economic development of the HRB. The mean annual available amount of water within this basin is $28.0 \times 10^{8} \mathrm{~m}^{3}$, of which surface water comprises $24.7 \times 10^{8} \mathrm{~m}^{3}$ and groundwater comprises $3.3 \times 10^{8} \mathrm{~m}^{3}$. In addition, 
the HRB is one of the ten largest commodity grain bases nationally; the main crops grown between March and September in this region include corn, wheat, barley, and oilseed rape. Agriculture is also the sector that consumes the most water in the HRB; irrigation water alone accounts for more than $85 \%$ of total water consumption in the basin. However, because of the lack of rainfall and runoff water, groundwater is used excessively in this area for irrigation. Because of the expansion of cultivated land area, rapid population growth, and urbanization in recent years, competition for water in the HRB among different sectors has become more-and-more intense, while the use of flood irrigation-oriented methods also waste a substantial volume, reducing agricultural water use efficiency to between $20 \%$ and $30 \%$. In the face of these issues, a number of aspects of current water management within the HRB are unreasonable; the irrigation quota, for example, is far higher than the actual $I W R_{c}$. It is therefore critical to develop management strategies for the use of agricultural water according to the spatiotemporal water requirements of crops in order to avoid water waste, yield losses, and environmental degradation.

\subsection{Data Sources}

We utilized TM/ETM+ RS images at a spatial resolution of $30 \mathrm{~m}$ and a temporal resolution of $16 \mathrm{~d}$ in this study to extract crop planting structures for 2007 and 2012 in the HRB. The images we selected were then subjected to a series of systematic radiometric, geometric, and atmospheric corrections, as well as radiometric calibration and de-striping to obtain a mosaic of HRB images that included seven time phases for 2007 and ten time phases for 2012. The numbers of useable mosaic images differed between the two years because of cloud cover; for both years, the number of effective mosaic images was far less than the total number of time phases.

We used ground monitoring data collected at 20 meteorological sites in the HRB and adjacent areas to calculate reference crop evapotranspiration (including under standard conditions), ER, and $I W R_{c}$. Meteorological data included mean monthly rainfall, temperature, maximum and minimum temperature, relative humidity, wind speed, and pressure for 2007 and 2012.

We then utilized the Advanced Spaceborne Thermal Emission and Reflection Radiometer Global Digital Elevation Model (ASTER GDEM) Version 2 elevation data with a spatial resolution of $30 \mathrm{~m}$ and an elevation resolution of $7 \mathrm{~m}$ to calculate net surface crop radiation [47]. Besides, phenological data from corn, wheat, barley, and oilseed rape were used to determine crop planting structures and coefficients at different growing stages.

\section{Methods}

\subsection{Mapping Crop Planting Structure}

\subsubsection{The Multi-Temporal Normalized Difference Vegetation-Water Index (NDVWI)}

We identified crop types in this study using the multi-temporal NDVWI, a new spectrum index that we developed based on the Normalized Difference Vegetation Index (NDVI) and the Normalized Difference Water Index (NDWI) [45]. Because the NDVI can effectively, empirically, and simply characterize vegetation growth status, it is one of the most widely used indexes in vegetation classification [48]. At the same time, the NDWI is sensitive to moisture in the vegetation canopy and is therefore also helpful for classification [49]. Our index, the NDVWI, combines the merits of both the NDVI and the NDWI and can achieve higher crop classification accuracy than either, especially in arid and semi-arid regions. Values for the NDVWI range between -2 and 2 and are dimensionless. The formula used to calculate this index is as follows:

$$
N D V W I=\frac{\rho(\text { nir })-\rho(\text { red })}{\rho(\text { nir })+\rho(\text { red })}+\frac{\rho(\text { nir })-\rho(\text { swir })}{\rho(\text { nir })+\rho(\text { swir })}
$$


In this expression, $\rho$ (red), $\rho$ (nir), and $\rho$ (swir) denote the surface reflectance of red, near-infrared, and short-wave infrared bands, the third, fourth, and fifth bands in TM/ETM+ images, respectively.

\subsubsection{Decision Tree Algorithm}

A decision tree algorithm is a top-down classification approach which is used to organize complex data sets step-by-step by effectively combining their characteristics with professional knowledge [45,50]. A decision tree comprises root, internal, and leaf nodes; of these, parent nodes (i.e., root or internal nodes) are further classified as child nodes (i.e., internal or leaf nodes) based on classification rules. Thus, applying the multi-temporal NDVWI as well as variations and differences in crop phenological information over time, we developed a series of classification rules for different crops by sample training in this study. Use of a classification decision tree enabled us to extract HRB crop planting structures for 2007 and 2012.

\subsection{The Thin Plate Spline (TPS) Method}

We applied a TPS method using the software ANUSPLIN to interpolate meteorological data. This method enables the spatial interpolation of multivariate data via comprehensive statistical analysis, data diagnosis, and the use of spatial distribution standard errors to allow the introduction of related covariates and increase interpolation precision [51].

\subsection{Effective Rainfall (ER)}

For agricultural production, ER refers to that portion of rainfall that can effectively be used by crops. This concept is important; not all rainfall is useful for agriculture as a component is always lost through runoff and infiltration. Thus, applying the method developed by the United States Department of Agriculture and Soil Conservation Service (USDA-SCS) [52], we calculated ER in monthly steps as follows:

$$
E R_{\text {month }}=\left\{\begin{array}{cl}
A R_{\text {month }} \times\left(125-0.2 \times A R_{\text {month }}\right) / 125 & \text { for } A R_{\text {month }} \leq 250 \mathrm{~mm} \\
125+0.1 \times A R_{\text {month }} & \text { for } A R_{\text {month }}>250 \mathrm{~mm}
\end{array}\right.
$$

In this expression, $E R_{\text {month }}$ and $A R_{\text {month }}$ refer to the effective and actual rainfall in each month, respectively.

\subsection{Reference Crop Evapotranspiration $\left(E T_{0}\right)$}

This measure, $E T_{0}$, refers to the evapotranspiration that would be recorded if the whole surface of the Earth were covered with hypothetical crops all growing actively with a sufficient water supply [53,54]. In 1990, the FAO convened a large group of experts and researchers to collaborate with the International Commission for Irrigation and Drainage and the World Meteorological Organization to jointly improve the $I W R_{c}$, calculation methodology. This process resulted in the development of the FAO Penman-Monteith method for the calculation of $E T_{o}[33,54]$. This approach overcomes the numerous shortcomings of earlier methods; $E T_{o}$ values calculated using the FAO Penman-Monteith method are more consistent with global actual crop water consumption data. We computed the FAO Penman-Monteith method as follows:

$$
\begin{gathered}
E T_{o}=\frac{0.408 \times \Delta \times\left(R_{n}-G\right)+\gamma \times \frac{900}{T_{\text {mean }}+273} \times u_{2} \times\left(e_{s}-e_{a}\right)}{\Delta+\gamma \times\left(1+0.34 u_{2}\right)} \\
\Delta=\frac{4098 \times e\left(T_{\text {mean }}\right)}{\left(T_{\text {mean }}+237.3\right)^{2}} \\
e(T)=0.6108 \times e^{\frac{17.27 T}{T+237.3}}
\end{gathered}
$$




$$
\begin{gathered}
e_{s}=\frac{e\left(T_{\max }\right)+e\left(T_{\min }\right)}{2} \\
e_{a}=R H \times e_{s} \\
\gamma=0.665 \times 10^{-3} \mathrm{P}
\end{gathered}
$$

and

$$
u_{2}=u_{z} \frac{4.87}{\ln (67.8 z-5.42)}
$$

In these expressions, $E T_{o}$ denotes reference crop evapotranspiration $(\mathrm{mm} / \mathrm{d}), R_{n}$ is crop surface net radiation $\left(\mathrm{MJ} \cdot \mathrm{m}^{-2} \cdot \mathrm{d}^{-1}\right), G$ is soil heat flux $\left(\mathrm{MJ} \cdot \mathrm{m}^{-2} \cdot \mathrm{d}^{-1}\right), \Delta$ is the slope of the saturated water vapor pressure curve $\left(\mathrm{kPa} /{ }^{\circ} \mathrm{C}\right), \gamma$ is the psychrometric constant $\left(\mathrm{kPa} /{ }^{\circ} \mathrm{C}\right), u_{2}$ is wind speed at a height of $2 \mathrm{~m}(\mathrm{~m} / \mathrm{s}), T_{\text {mean }}, T_{\max }$, and $T_{\min }$ refer to mean temperature, mean maximum temperature, and mean minimum temperature, respectively $\left({ }^{\circ} \mathrm{C}\right), e_{S}$ denotes the saturated water vapor pressure $(\mathrm{kPa})$, $e_{a}$ is the actual water vapor pressure $(\mathrm{kPa}), e\left(T_{\text {mean }}\right), e\left(T_{\max }\right)$, and $e\left(T_{\min }\right)$ are water vapor pressures at temperatures of $T_{\text {mean }}, T_{\max }$, and $T_{\min }$, respectively, $R H$ is relative humidity (\%), $P$ is atmospheric pressure $(\mathrm{kPa})$, and $z$ is the elevation from the surface of the Earth when measuring wind speed.

\subsection{Crop Evapotranspiration under Standard Conditions $\left(E T_{\mathcal{c}}\right)$}

In this context, $E T_{c}$ is defined as crop evapotranspiration when a particular plant is growing actively with sufficient water supply under standard conditions. Similarly, the crop coefficient $\left(K_{c}\right)$ distinguishes a specific crop from the reference [33,55]. We calculated $E T_{\mathcal{c}}(\mathrm{mm})$ for the major crops grown in the HRB for the period between March and September as follows:

$$
E T_{c}=E T_{o} \times K_{c}
$$

However, because $K_{c}$ varies with plant growth period, we corrected and determined this value for different crop stages using a survey based on FAO Irrigation and Drainage Paper No. 56 [54] and crop phenological information (Table 1). Oilseed rape and corn are autumn crops, so their growth stages are longer than those of summer crops such as barley and wheat; the growth phase of oilseed rape is between April and August, while that of corn is between April and September, those of barley and wheat are between March and July, and those of other crops are between April and August.

Table 1. $K_{c}$ values for different crop growth stages within the HRB in 2007 and 2012.

\begin{tabular}{cccccccccc}
\hline \multirow{2}{*}{ Crop } & \multirow{2}{*}{$\begin{array}{c}\text { Sowing } \\
\text { Date }\end{array}$} & \multicolumn{2}{c}{ Initial Stage } & \multicolumn{2}{c}{ Development Stage } & \multicolumn{2}{c}{ Mid-Season Stage } & \multicolumn{2}{c}{ End-Season Stage } \\
\cline { 3 - 9 } & & Duration (d) & $\boldsymbol{K}_{\boldsymbol{c} \text { ini }}$ & Duration (d) & $\boldsymbol{K}_{\boldsymbol{c} \text { dev }}$ & Duration (d) & $\boldsymbol{K}_{\boldsymbol{c} \text { mid }}$ & Duration (d) & $\boldsymbol{K}_{\boldsymbol{c}}$ end \\
\hline Oilseed rape & 10 April & 30 & 0.35 & 36 & 0.73 & 35 & 1.10 & 32 \\
Corn & 15 April & 30 & 0.10 & 56 & 0.56 & 57 & 1.02 & 21 & 0.73 \\
Barley & 20 March & 30 & 0.30 & 43 & 0.78 & 26 & 1.25 & 22 & 0.75 \\
Wheat & 20 March & 30 & 0.30 & 50 & 0.77 & 26 & 1.24 & 22 \\
Others & 1 April & 30 & 0.26 & 46 & 0.71 & 36 & 1.15 & 24 & 0.77 \\
\hline
\end{tabular}

Note: Values for the duration and $K_{c}$ of others (i.e., other crops) are mean values for the four main crops at different growth stages.

\subsection{Crop Irrigation Water Requirement $\left(I W R_{c}\right)$}

In this context, $I W R_{c}$ is the volume of water required to replenish losses due to evapotranspiration. This value is the difference between $E R$ and $E T_{\mathcal{C}}$ [54], calculated as follows:

$$
I W R_{c}=\left\{\begin{array}{cl}
E T_{c}-E R & \text { for } E T_{c}>E R \\
0 & \text { for } E T_{c}<E R
\end{array}\right.
$$




\section{Results}

\subsection{Spatiotemporal ER Changes}

Results show that between 2007 and 2012, ER values in the HRB were non-uniform in their spatiotemporal distribution (Figure 2). Specifically, annual ER values gradually fell along an upstream-to-downstream transect; in the upper reaches of the HRB, annual ER was higher than $250 \mathrm{~mm}$, while values were between $100 \mathrm{~mm}$ and $200 \mathrm{~mm}$ in the middle reaches, falling to below $100 \mathrm{~mm}$ in the lower reaches. Data show that the annual mean ER of the HRB decreased from $139.49 \mathrm{~mm}$ in 2007 to $106.29 \mathrm{~mm}$ in 2012 (Figure 2a,b). Thus, given the same evapotranspiration, decreasing ER means that the $I W R_{c}$ in 2012 was greater than that of the same crop in 2007. Monthly $E R$ also significantly differed within the same year, exhibiting a tendency to initially increase before decreasing (Figure 2c,d). In both years, mean and minimum ER values were highest in July; highest monthly maximum values were recorded in June 2007 and in July 2012, while within each year, 70\% of ER was concentrated between June and August. Results show that mean ER values in June 2007, July 2007, and August 2007 were 17.99, 41.68, and $19.29 \mathrm{~mm}$, respectively, while in June 2012, July 2012, and August 2012 they were 26.82, 34.56, and $16.65 \mathrm{~mm}$, respectively. Interestingly, mean $E R$ values in April 2007 (16.79 mm) and September $2007(20.97 \mathrm{~mm})$ were significantly higher than those in April $2012(4.42 \mathrm{~mm})$ and September $2012(5.74 \mathrm{~mm})$. Some growth phases of dominant crops were also characterized by lowered ER values, including the seeding period between March and April, and the late growing period in September. In contrast, some fast growth periods, including between May and June and the intermediate phase between July and August were characterized by higher ER values. In other months, ER values were lower that those seen during crop growth periods (i.e., in January, February, October, November, and December).

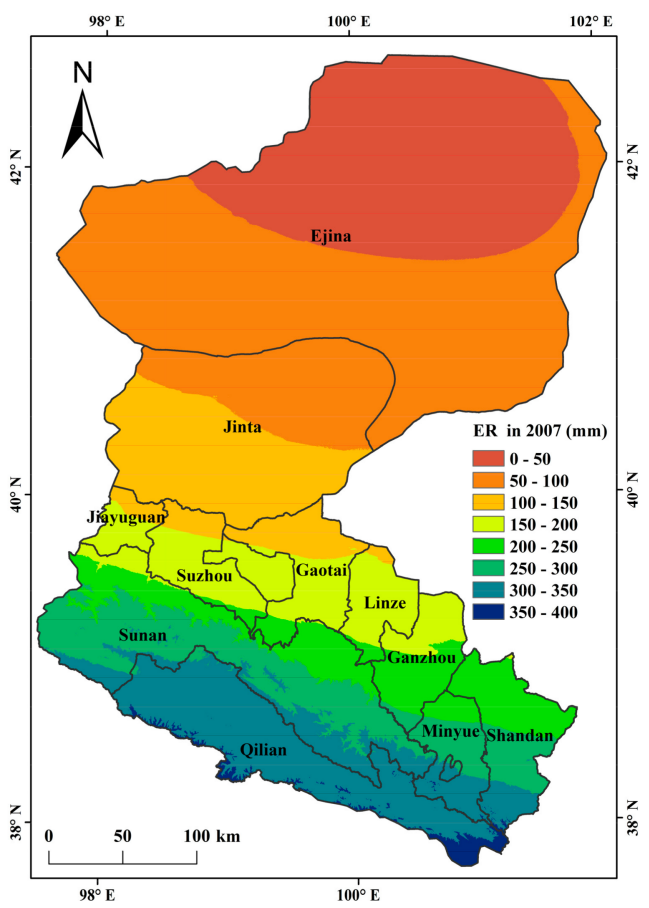

(a)

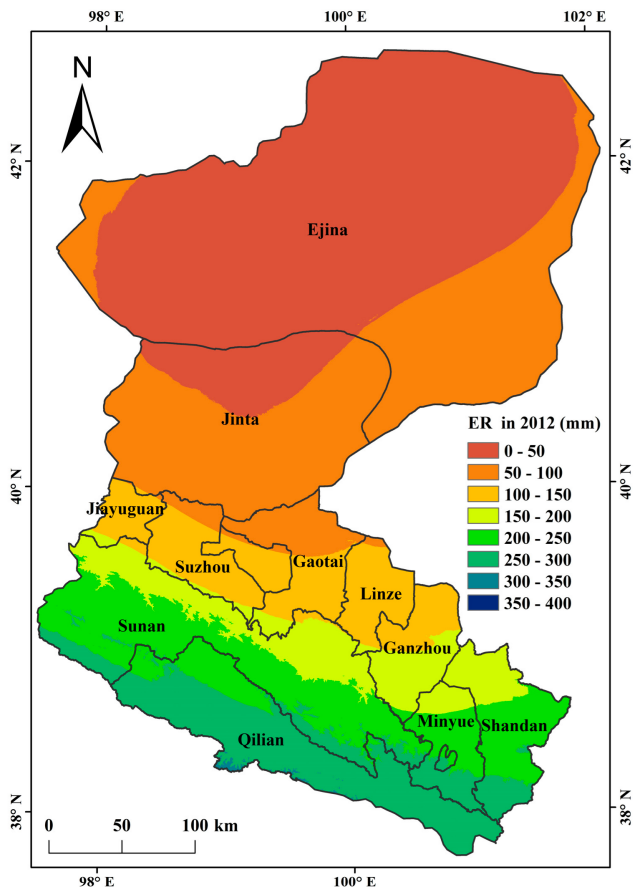

(b)

Figure 2. Cont. 


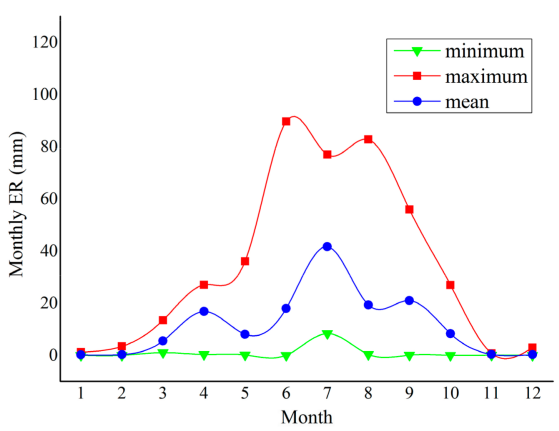

(c)

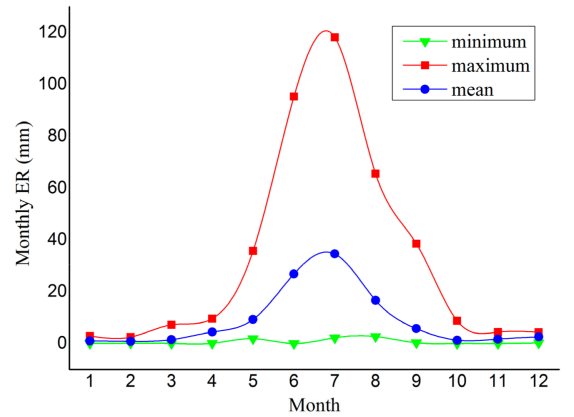

(d)

Figure 2. $E R$ within the HRB in 2007 and 2012: (a) Spatial distribution of $E R$ in 2007; (b) Spatial distribution of $E R$ in 2012; (c) Monthly mean, maximum, and minimum ER in 2007; (d) Monthly mean, maximum, and minimum ER in 2012.

\subsection{Spatiotemporal Changes in Crop Evapotranspiration}

\subsubsection{Spatiotemporal Changes in $E T_{o}$}

Data show that annual $E T_{o}$ values for the HRB tend to increase along an upstream-to-downstream transect. Thus, in water conservation areas in the upper reaches, values were as low as $750 \mathrm{~mm}$, increasing to between 750 and $1250 \mathrm{~mm}$ in agricultural oases regions in the middle reaches, and were higher, between 1250 and $2500 \mathrm{~mm}$, in the lower reaches. Annual $E T_{o}$ exceeded $1750 \mathrm{~mm}$ in the northeastern ecological conservation area in the lower reaches of the HRB (Figure 3a,b). Results show that between 2007 and 2012, mean annual $E T_{o}$ decreased from 1406.04 to $1392.44 \mathrm{~mm}$; monthly mean $E T_{o}$ values in 2007 and 2012 were between 0.67 and $8.42 \mathrm{~mm} / \mathrm{d}$ (mean: $3.84 \mathrm{~mm} / \mathrm{d}$ ) and between 0.54 and $7.52 \mathrm{~mm} / \mathrm{d}$ (mean: $3.80 \mathrm{~mm} / \mathrm{d}$ ), respectively. Mean $E T_{o}$ in June was highest (Figure 3c,d), while monthly minimum $E T_{o}$ values in 2007 and 2012 were 1.34 and $1.46 \mathrm{~mm} / \mathrm{d}$, respectively. The lowest recorded monthly minimum $E T_{o}$ values in $2007(0.36 \mathrm{~mm} / \mathrm{d})$ and $2012(0.30 \mathrm{~mm} / \mathrm{d})$ were both in January, while mean values of monthly maximum $E T_{o}$ in 2007 and 2012 were 6.66 and $6.70 \mathrm{~mm} / \mathrm{d}$, respectively. Highest monthly maximum $E T_{o}$ values were recorded in June $2007(16.63 \mathrm{~mm} / \mathrm{d})$ and July $2012(15.34 \mathrm{~mm} / \mathrm{d})$; results show that standard variations in mean monthly $E T_{o}$ were 1.40 and $1.23 \mathrm{~mm} / \mathrm{d}$ in the two years, respectively, and that monthly $E T_{o}$ values were greater in 2007 than they were in 2012. During the main growth phases of dominant crops, mean $E T_{0}$ values were higher during fast and medium growing stages in the months between June and August; values of 7.77, 8.42, 6.60, and $6.43 \mathrm{~mm} / \mathrm{d}$, respectively, were recorded in 2007, compared to $6.56,7.52,6.90$, and $6.65 \mathrm{~mm} / \mathrm{d}$, respectively, in 2012.

\subsubsection{Spatiotemporal Changes in $\mathrm{ET}_{\mathrm{C}}$}

Results show that annual $E T_{c}$ values within the HRB exhibit similar spatial variation to annual $E T_{o}$; increasing along an upstream-to-downstream transect (Figure $\left.4 \mathrm{a}, \mathrm{b}\right)$. As a small proportion of cultivated land within the upper reaches of the HRB is located in the river valley, annual $E T_{\mathcal{c}}$ was as low as $375 \mathrm{~mm}$ in this area. In contrast, $85 \%$ of cultivated land is within oases in the middle reaches where annual $E T_{c}$ values fall between 375 and $625 \mathrm{~mm}$. In the lower reaches, the annual $E T_{c}$ of cultivated land in the Gobi Desert was between 625 and $1125 \mathrm{~mm}$, while values for this land use type in the northeast exceeded $1000 \mathrm{~mm}$. Results show that mean $E T_{c}$ was $483.87 \mathrm{~mm}$ in 2007 and that it increased to $500.38 \mathrm{~mm}$ in 2012; during crop growth phases, mean, maximum, and minimum $E T_{c}$ values for May, June, and July (middle growth stage) were relatively elevated, while those for early and late growth stages were relatively lower (Figure 4c,d). Mean HRB $E T_{\mathcal{c}}$ values for May 2007, June 2007, and July 2007 were $100.28,144.53$, and $141.32 \mathrm{~mm}$, respectively, while they were $101.69,143.95$, and $142.24 \mathrm{~mm}$, respectively, in 2012. 


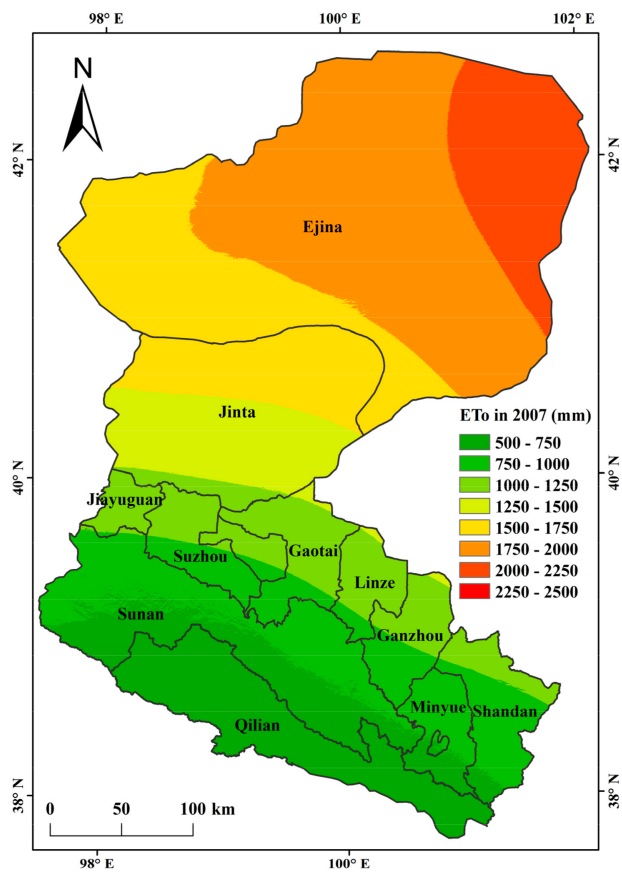

(a)

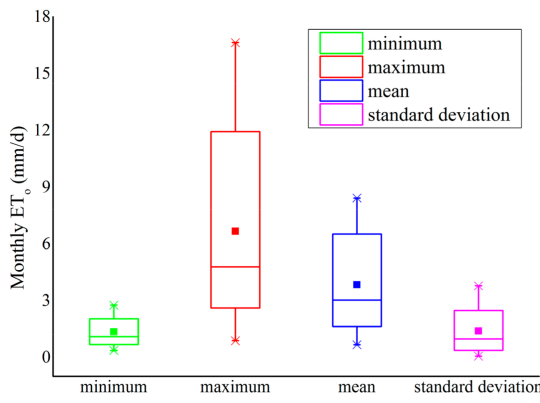

(c)

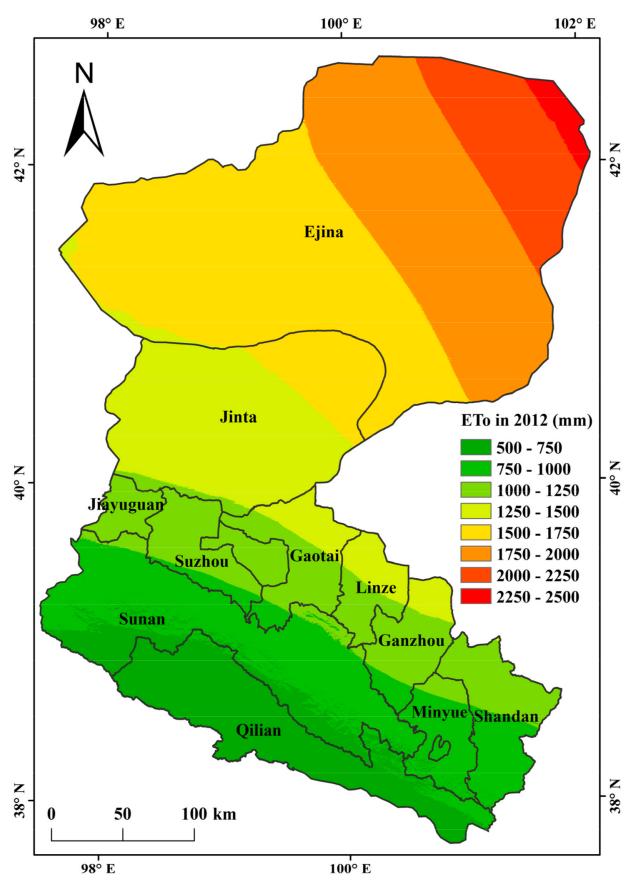

(b)

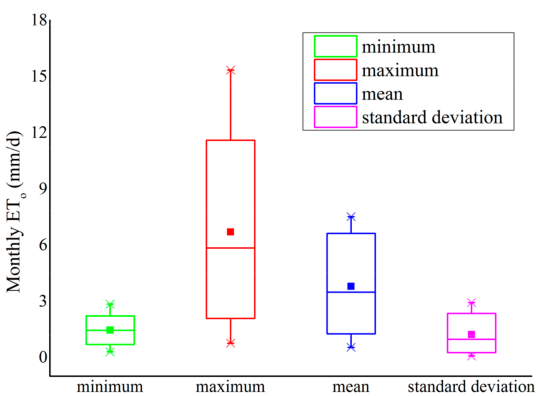

(d)

Figure 3. HRB $E T_{o}$ values for 2007 and 2012: (a) Spatial distribution of $E T_{o}$ in 2007; (b) Spatial distribution of $E T_{o}$ in 2012; (c) Monthly mean, maximum, and minimum $E T_{o}$, as well as monthly standard deviation for 2007; (d) Monthly mean, maximum, and minimum $E T_{0}$, as well as monthly SD for 2012.

Data show that mean $E T_{c}$ values for oilseed rape, corn, barley, and other crops increased from $394.26,495.11,377.89$, and $495.32 \mathrm{~mm}$, respectively, in 2007 to $417.03,521.50,393.53$, and $506.58 \mathrm{~mm}$ in 2012. Interestingly, the mean $E T_{\mathcal{c}}$ of wheat decreased from $418.94 \mathrm{~mm}$ in 2007 to $411.39 \mathrm{~mm}$ in 2012 (Figure 4e,f); mean values for barley and wheat were at their highest in June 2007, 161.40 and $160.98 \mathrm{~mm}$, respectively, but increased in 2012 to 178.77 and $165.48 \mathrm{~mm}$, respectively. Mean $E T_{c}$ values for barley and wheat in May 2007 were relatively higher, 113.66 and $117.39 \mathrm{~mm}$, respectively, but fell to 101.65 and $101.83 \mathrm{~mm}$, respectively, in 2012. Oilseed rape was characterized by higher mean $E T_{\mathcal{C}}$ values in June and July of each year; mean values in 2007 were 116.59 and $122.68 \mathrm{~mm}$, respectively, and 133.19 and $120.65 \mathrm{~mm}$ in 2012. Similarly, corn was characterized by relatively higher mean $E T_{c}$ values, 133.57 and $136.13 \mathrm{~mm}$, in July 2007 and August 2007, respectively, and these values rose to $130.62 \mathrm{~mm}$ and $155.98 \mathrm{~mm}$, respectively, in 2012. Other crops also had higher mean $E T_{c}$ values in May 2007, June 2007, and July 2007, 122.20, 154.06, and $151.90 \mathrm{~mm}$, respectively, corresponding to 115.50, 156.52, and $152.51 \mathrm{~mm}$, respectively, in 2012. 


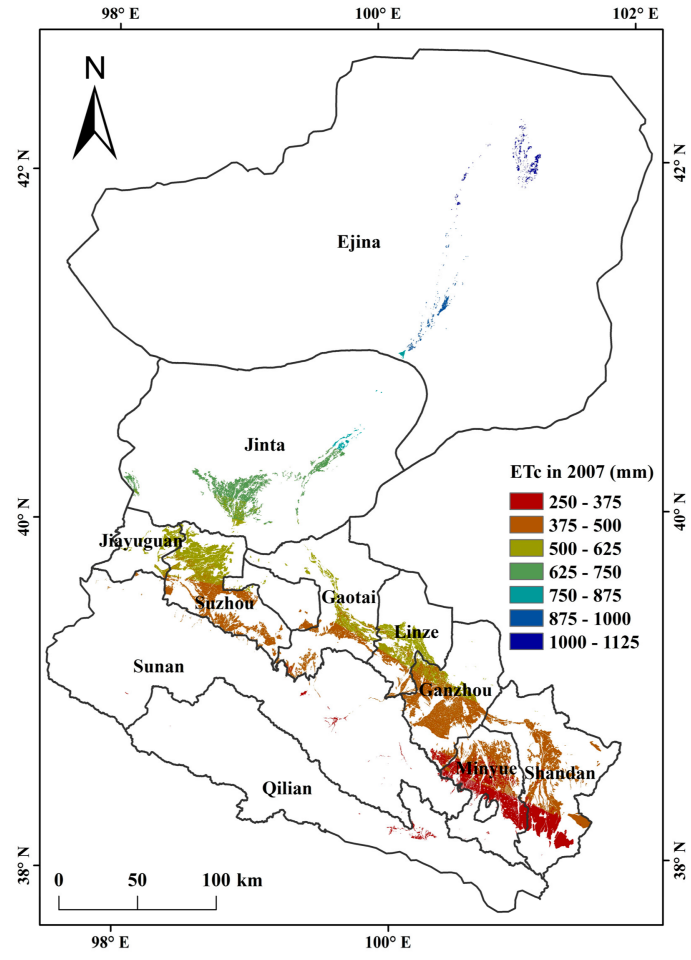

(a)

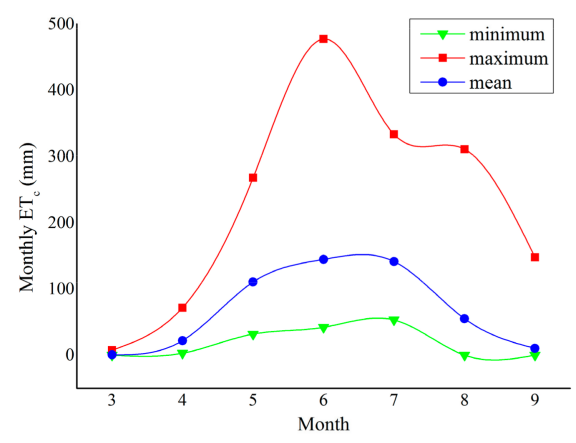

(c)

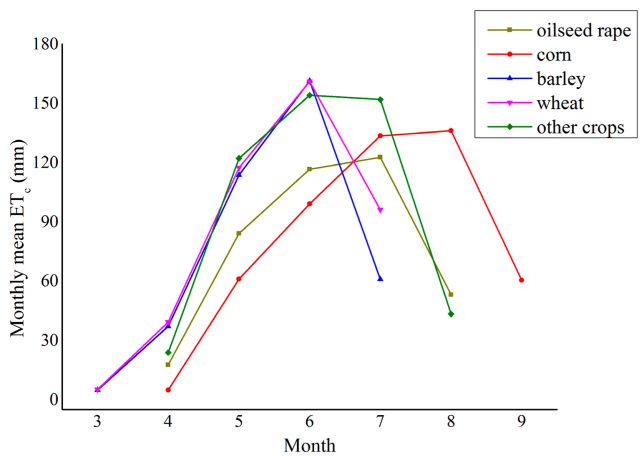

(e)

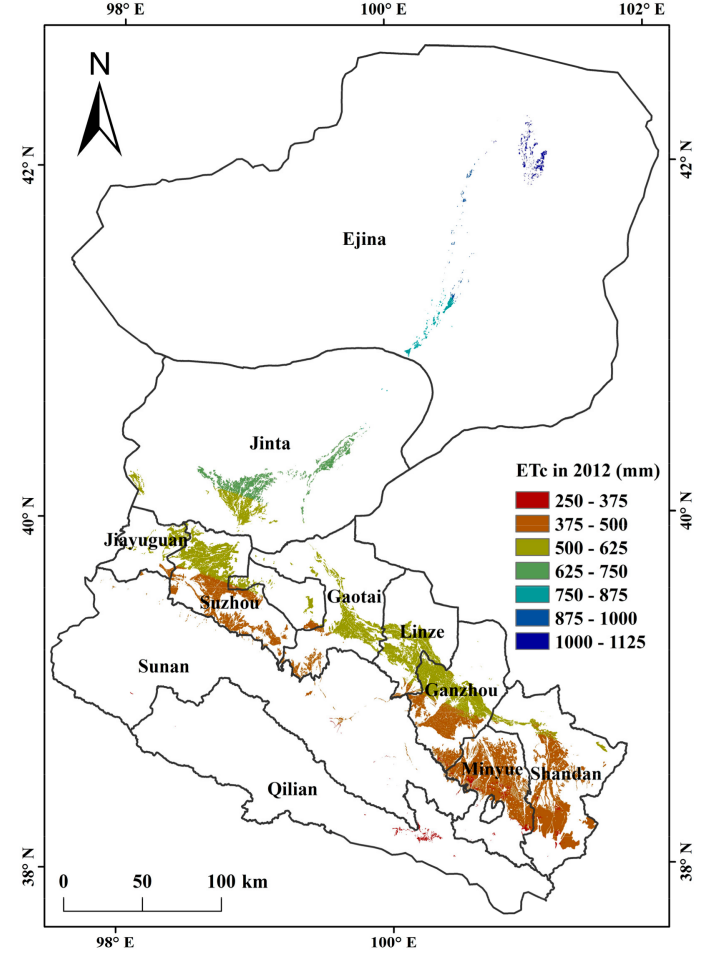

(b)

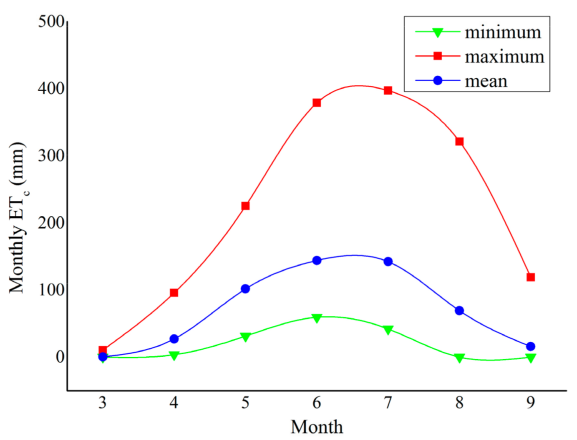

(d)

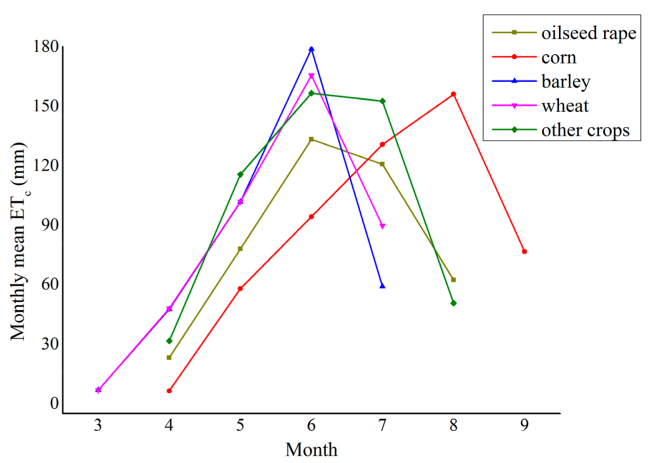

(f)

Figure 4. HRB $E T_{\mathcal{c}}$ values for 2007 and 2012: (a) Spatial distribution of $E T_{\mathcal{c}}$ in 2007; (b) Spatial distribution of $E T_{c}$ in 2012; (c) Monthly mean, maximum, and minimum $E T_{c}$ for 2007; (d) Monthly mean, maximum, and minimum $E T_{c}$ for 2012; (e) Monthly mean $E T_{\mathcal{c}}$ of different crops in 2007; (f) Monthly mean $E T_{\mathcal{c}}$ of different crops in 2012. 


\subsection{Spatiotemporal Changes in $I W R_{c}$}

Results show that annual $I W R_{c}$ values within the HRB tend to increase along an upstream-to-downstream transect (Figure 5a,b). Thus, in 2012, the number of regions with $I W R_{c}$ values between zero and $150 \mathrm{~mm}$ in the upper reaches decreased compared to 2007; a similar trend was seen in the number of regions with $I W R_{c}$ values between 150 and $300 \mathrm{~mm}$ in the middle reaches, while the values of some regions increased to between 300 and $450 \mathrm{~mm}$ over the time period of this study. At the same time, some regions with initial (2007) $I W R_{c}$ values between 300 and $450 \mathrm{~mm}$ increased to between 450 and $600 \mathrm{~mm}$, while the number of regions with values greater than $1050 \mathrm{~mm}$ in the lower reaches also fell. These changes resulted in an overall increase in annual mean $I W R_{c}$, from $339.95 \mathrm{~mm}$ in 2007 to $370.11 \mathrm{~mm}$ in 2012. Data also show that in both years, 2007 and 2012, mean $I W R_{c}$ values in May, June, and July were all higher (Figure 5c); values were 96.36, 114.01, and $88.39 \mathrm{~mm}$ in 2007, and 88.22, 102.34, and $94.14 \mathrm{~mm}$ in 2012, respectively. Considering these 2012 values (Figure 2c,d), variation in mean $I W R_{c}$ between the three major water-consuming months might help to ease the imbalance between irrigation water supply and demand. Data show that the mean $I W R_{\mathcal{c}}$ values for March 2007, April 2007, August 2007, and September 2007 also increased, from 0.01, 4.05, 31.96, and $4.05 \mathrm{~mm}$, respectively, to $0.20,22.32,48.99$, and $13.91 \mathrm{~mm}$ in 2012 .

The results of this study show that mean $I W R_{c}$ values for oilseed rape, corn, barley, and other crops also increased, from 208.43, 349.35, 229.26, and $352.85 \mathrm{~mm}$, respectively, in 2007 to 241.81, 393.10, 251.17 , and $378.86 \mathrm{~mm}$, respectively, in 2012. In contrast, mean $I W R_{c}$ values for wheat decreased from $281.53 \mathrm{~mm}$ in 2007 to $266.69 \mathrm{~mm}$ in 2012 (Figure 5d). These results suggest that barley and wheat should mostly be irrigated in May and June, oilseed rape and other crops should mostly be irrigated in May, June, and July, and corn should mostly be irrigated in July and August (Figure 5e,f). Highest mean $I W R_{c}$ values for oilseed rape, barley, wheat, and other crops were recorded in June; mean values for 2007 were $67.20,116.60,122.32$, and $124.03 \mathrm{~mm}$, respectively, while the corresponding values for 2012 were 77.32, 119.95, 107.87, and $117.08 \mathrm{~mm}$, respectively. The highest mean $I W R_{c}$ for corn was recorded in August; $112.04 \mathrm{~mm}$ in 2007 and $135.76 \mathrm{~mm}$ in 2012, while in 2007 and 2012, the mean $I W R_{c}$ of barley and wheat increased in March. Mean $I W R_{c}$ values of all crops increased in April and decreased in May, while the mean values for crops still growing tended to increase between August and September.

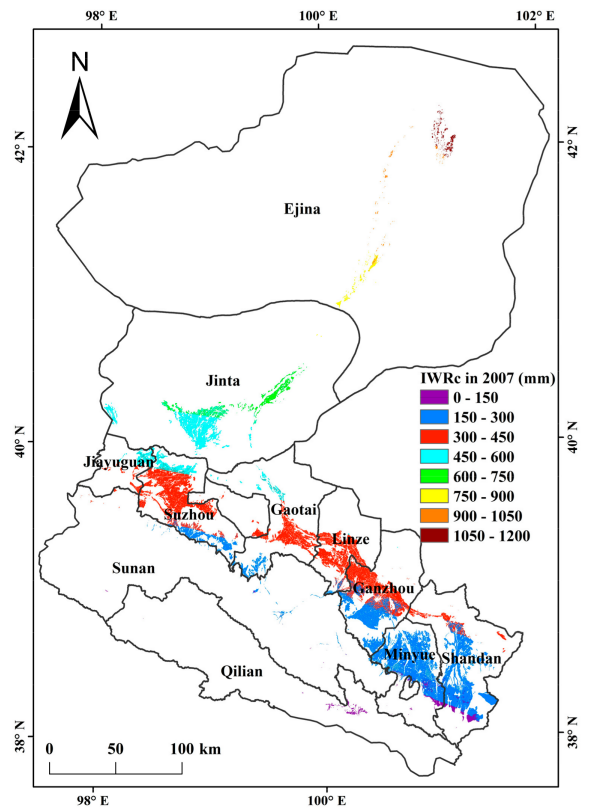

(a)

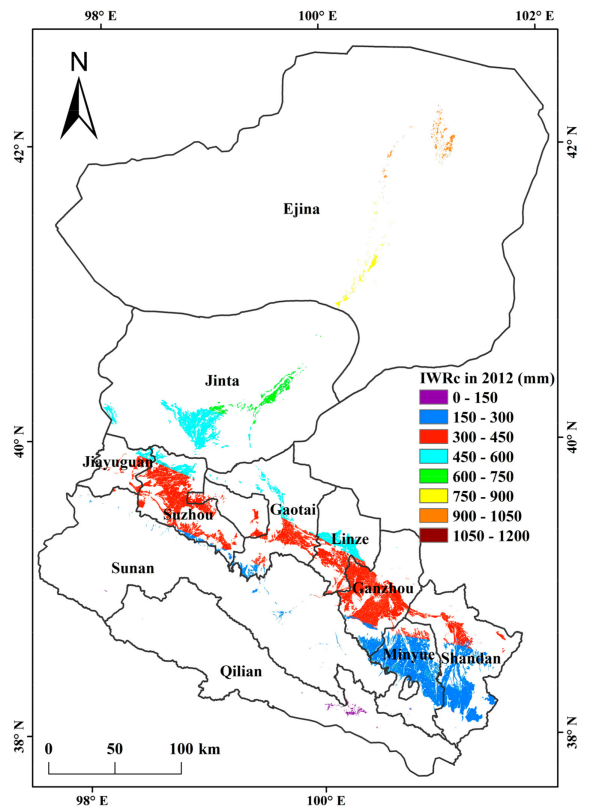

(b)

Figure 5. Cont. 


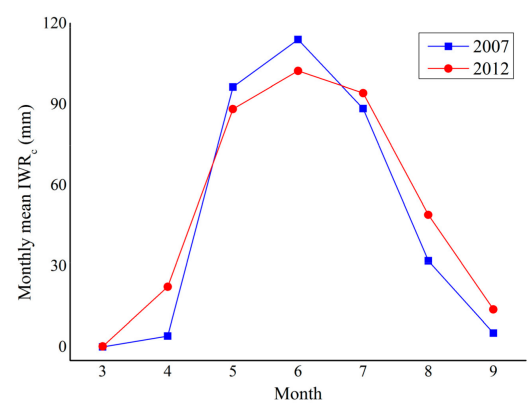

(c)

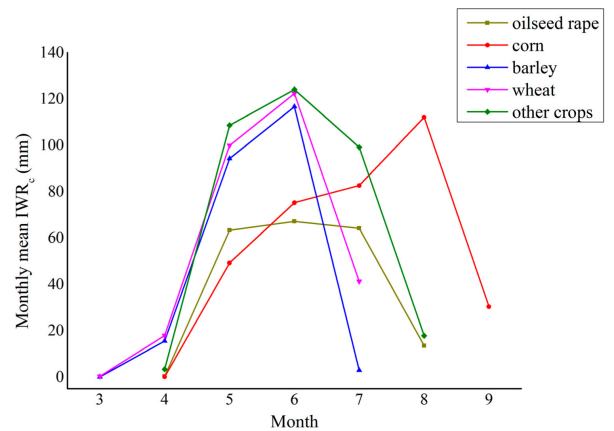

(e)

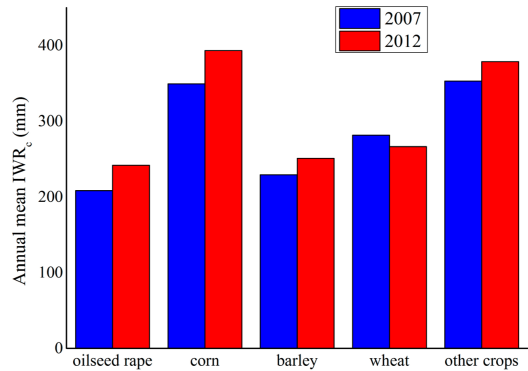

(d)

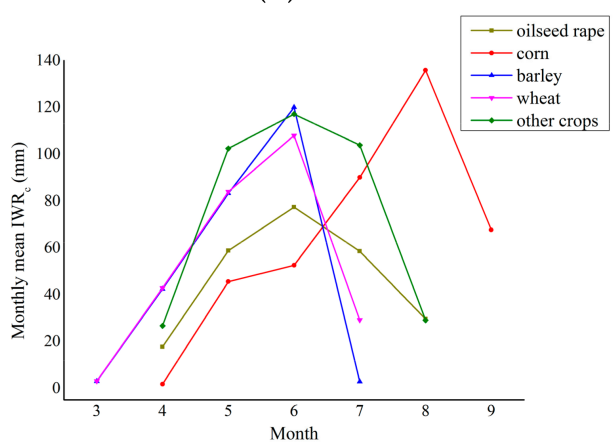

(f)

Figure 5. HRB $I W R_{c}$ values for 2007 and 2012: (a) Spatial distribution of $I W R_{c}$ in 2007; (b) Spatial distribution of $I W R_{c}$ in 2012; (c) Monthly mean $I W R_{c}$ for 2007 and 2012; (d) Annual mean $I W R_{c}$ of different crops in 2007 and 2012; (e) Monthly mean $I W R_{c}$ of different crops in 2007; (f) Monthly mean $I W R_{c}$ of different crops in 2012.

\subsection{The Influence of Changes in Crop Planting Structure on IWR}

Corn is planted over the largest area within the HRB, followed by wheat, oilseed rape, and barley (Figure 6a,b). The most crop is planted mainly in Ganzhou, Linze, Gaotai, Suzhou, and Jinta counties, while oilseed rape, barley, and wheat are mainly planted in Minle and Shandan counties. Corn cultivation extends from northwestern high-latitude regions to southeastern high-elevations and planting is usually concentrated. In contrast, oilseed rape, barley, and wheat tend to be planted in a more scattered fashion within the HRB. Nevertheless, between 2007 and 2012, areas planted with oilseed rape and corn increased by $3.65 \times 10^{3}$ and $31.31 \times 10^{3}$ ha, respectively (Table 2), while those planted with barley, wheat, and other crops decreased by $8.08 \times 10^{3}, 12.24 \times 10^{3}$, and $18.51 \times 10^{3}$ ha, respectively. In 2012, the cultivated land area in the HRB was $727.50 \times 10^{3}$ ha, an increase of $33.15 \times 10^{3}$ ha $(4.77 \%)$ compared to 2007 .

These changes in planting structure resulted in a $I W R_{c}$ increase within the HRB. Data show that in 2012 , the $I W R_{c}$ of the HRB was $2692.58 \times 10^{6} \mathrm{~m}^{3}, 14.07 \%$ higher than in 2007 (Table 2). At the same time, between 2007 and 2012, IWR values for oilseed rape, corn, and other crops increased by $14.29 \times 10^{6} \mathrm{~m}^{3}(41.88 \%), 174.80 \times 10^{6} \mathrm{~m}^{3}(42.33 \%)$, and $197.67 \times 10^{6} \mathrm{~m}^{3}(11.43 \%)$, respectively, while those for barley and wheat decreased by $15.14 \times 10^{6} \mathrm{~m}^{3}(28.10 \%)$ and $39.46 \times 10^{6} \mathrm{~m}^{3}(30.52 \%)$. 


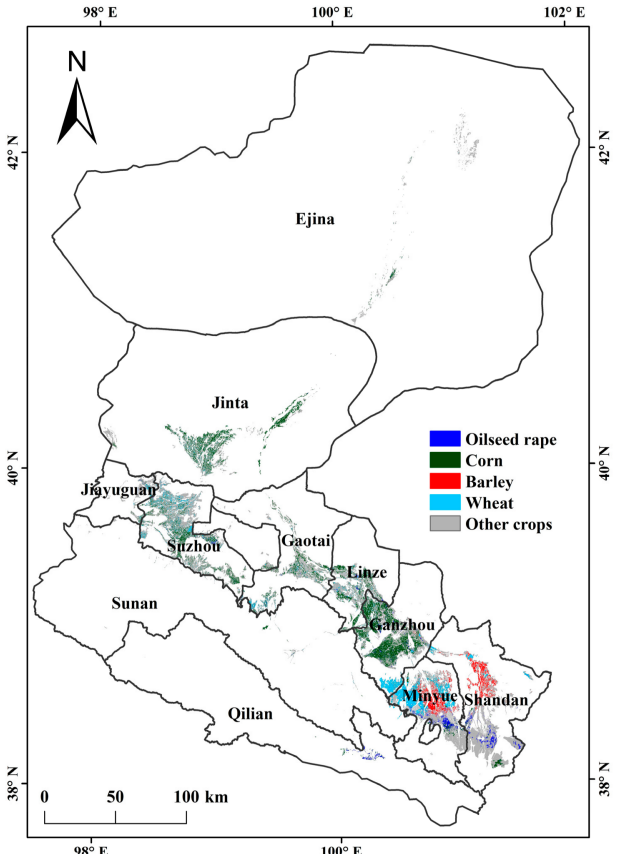

(a)

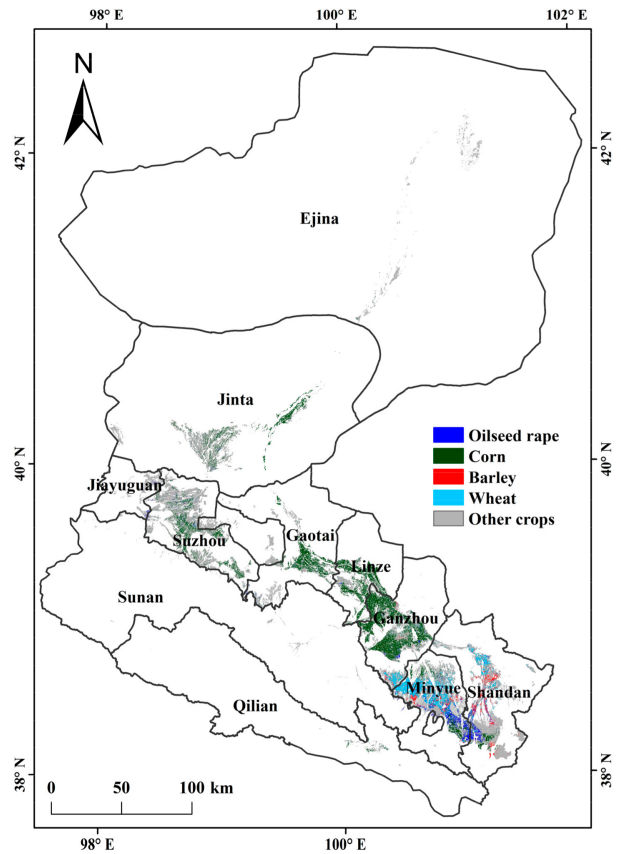

(b)

Figure 6. Maps to show the spatiotemporal distribution of crop planting within the HRB in (a) 2007 and (b) 2012.

Table 2. Changes in HRB crop planting area and $I W R_{c}$ between 2007 and 2012.

\begin{tabular}{|c|c|c|c|c|c|c|c|c|c|}
\hline \multirow{2}{*}{ Crop Type } & \multicolumn{3}{|c|}{ Planting Area $\left(10^{3}\right.$ ha) } & \multicolumn{3}{|c|}{$I W R_{c}$ per Unit Area $\left(\mathrm{m}^{3} / \mathrm{ha}\right)$} & \multicolumn{3}{|c|}{ Total $I W R_{c}\left(10^{6} \mathrm{~m}^{3}\right)$} \\
\hline & 2007 & 2012 & Change & 2007 & 2012 & Change & 2007 & 2012 & Change \\
\hline Oilseed rape & 16.37 & 20.02 & 3.65 & 2084.35 & 2418.08 & 333.74 & 34.12 & 48.41 & 14.29 \\
\hline Corn & 118.21 & 149.52 & 31.31 & 3493.53 & 3931.04 & 437.51 & 412.97 & 587.77 & 174.80 \\
\hline Barley & 23.51 & 15.43 & -8.08 & 2292.60 & 2511.72 & 219.12 & 53.90 & 38.76 & -15.14 \\
\hline Wheat & 45.92 & 33.68 & -12.24 & 2815.27 & 2666.86 & -148.41 & 129.28 & 89.82 & -39.46 \\
\hline Other crops & 490.34 & 508.85 & 18.51 & 3528.48 & 3788.59 & 260.11 & 1730.15 & 1927.83 & 197.67 \\
\hline Cropland & 694.35 & 727.50 & 33.15 & 3399.45 & 3701.12 & 301.67 & 2360.42 & 2692.58 & 332.16 \\
\hline
\end{tabular}

Data reveal a relatively large increase in the area of planted corn between 2007 and 2012 in Ganzhou, Linze, and Gaotai counties; 12,180.06, 11,941.02, and 11,941.02 ha, respectively. Over the same period, the corresponding area of planted corn in Jinta County decreased by 8135.37 ha (Table 3), while the area of planted wheat increased in just Minle and Shandan counties; 915.30 and 5092.83 ha, respectively. The areas of wheat cultivation in Ganzhou and Suzhou counties decreased significantly, by 4219.29 and 6805.26 ha, respectively, while planted areas of barley decreased by 6340.59 and 3591.54 ha, respectively, in Minle and Shandan counties and increased by 1418.31 ha in Ganzhou County. The planted area of oilseed rape in Minle County increased by as much as 5086.26 ha, but decreased significantly by 1157.58 and 1211.58 ha in Ganzhou and Qilian counties, respectively. The planted areas of other crops increased by 10,312.63 and 10,678.99 ha in Sunan and Jinta counties, respectively, but decreased by 7115.14 and 4298.19 ha in Linze and Gaotai counties, respectively. Changes to crop planting structures resulted in increased $I W R_{c}$ values in Ganzhou, Minle, Shandan, Linze, Gaotai, Sunan, Suzhou, Jinta, and Qilian counties; increases of $99.01 \times 10^{6}, 65.59 \times 10^{6}$, $39.53 \times 10^{6}, 34.37 \times 10^{6}, 40.22 \times 10^{6}, 16.16 \times 10^{6}, 5.41 \times 10^{6}$, and $1.33 \times 10^{6} \mathrm{~m}^{3}$, respectively. Over the same time period, however, $I W R_{c}$ values decreased in Jiayuguan and Egina counties; reductions of $1.51 \times 10^{6}$ and $6.80 \times 10^{6} \mathrm{~m}^{3}$, respectively. 
Table 3. HRB county-level changes in crop planting area and $I W R_{c}$ values between 2007 and 2012.

\begin{tabular}{ccccccccc}
\hline \multirow{2}{*}{ County } & \multicolumn{4}{c}{ Changes in Crop Planting Area (ha) } & \multicolumn{3}{c}{ Changes of Total $\mathbf{I W R}_{\boldsymbol{c}}\left(\mathbf{1 0}^{\mathbf{6}} \mathbf{~ m}^{\mathbf{3}}\right)$} \\
\cline { 2 - 9 } & Oilseed Rape & Corn & Barley & Wheat & Other Crops & $\mathbf{2 0 0 7}$ & $\mathbf{2 0 1 2}$ & Change \\
\hline Ganzhou & -1157.58 & $12,180.06$ & 1418.31 & -4219.29 & 155.09 & 366.24 & 465.25 & 99.01 \\
Minle & 5086.26 & 5924.07 & -6340.59 & 915.30 & 1644.33 & 225.74 & 291.33 & 65.59 \\
Shandan & 405.36 & 2257.65 & -3591.54 & 5092.83 & -2829.03 & 228.86 & 268.39 & 39.53 \\
Linze & -469.62 & $11,941.02$ & 8.64 & -2069.64 & -7115.14 & 207.61 & 247.08 & 39.47 \\
Gaotai & -98.82 & 8488.89 & 0.81 & -2062.71 & -4298.19 & 191.43 & 225.80 & 34.37 \\
Sunan & 126.54 & -1125.54 & 52.20 & -511.56 & $10,312.63$ & 36.51 & 76.73 & 40.22 \\
Suzhou & 374.13 & 1097.46 & 276.75 & -6805.26 & 6231.75 & 459.84 & 476.00 & 16.16 \\
Jinta & 334.71 & -8135.37 & 53.91 & -1747.80 & $10,678.99$ & 418.61 & 424.02 & 5.41 \\
Jiayuguang & 286.20 & -782.73 & 36.18 & -728.10 & 1663.32 & 70.93 & 69.43 & -1.51 \\
Egina & -17.28 & -715.32 & 0.00 & -82.26 & 917.89 & 150.41 & 143.61 & -6.80 \\
Qilian & -1211.58 & 175.50 & 8.64 & -24.39 & 1151.96 & 3.49 & 4.82 & 1.33 \\
\hline
\end{tabular}

Changes in crop planting between 2007 and 2012 in the HRB resulted in an $I W R_{c}$ increase of $76.77 \times 10^{6} \mathrm{~m}^{3}, 23.11 \%$ of the total (Table 4 ). The area of corn transferred from other crop types was the largest, up to $72.58 \times 10^{3}$ ha, accounting for $29.22 \times 10^{6} \mathrm{~m}^{3}(8.80 \%)$ of the total $I W R_{c}$ increment. The areas of other crops transferred from oilseed rape, corn, barley, and wheat were also relatively large, $8.16 \times 10^{3}, 46.25 \times 10^{3}, 11.27 \times 10^{3}$, and $26.41 \times 10^{3}$ ha, respectively; these equate to contributions of $13.91 \times 10^{6} \mathrm{~m}^{3}(4.19 \%), 13.65 \times 10^{6} \mathrm{~m}^{3}(4.11 \%), 16.86 \times 10^{6} \mathrm{~m}^{3}(5.08 \%)$, and $25.71 \times 10^{6} \mathrm{~m}^{3}(7.74 \%)$ of the total $I W R_{c}$ increment, respectively. In contrast, transfer of other crops to oilseed rape, barley, and wheat were largely negative in their contributions, decreasing the total $I W R_{c}$ increment within the HRB by $14.97 \times 10^{6} \mathrm{~m}^{3}(4.51 \%), 8.25 \times 10^{6} \mathrm{~m}^{3}(2.48 \%)$, and $10.07 \times 10^{6} \mathrm{~m}^{3}(3.03 \%)$, respectively. The remaining change in total $I W R_{c}, 76.89 \%\left(255.39 \times 10^{6} \mathrm{~m}^{3}\right)$, was the direct result of the cultivated land expansion (i.e., the transfer of other land use types to agriculture).

Table 4. Crop conversion contributions to $I W R_{c}$ changes within the HRB between 2007 and 2012.

\begin{tabular}{|c|c|c|c|c|c|c|c|}
\hline $\begin{array}{c}\text { Conversion } \\
\text { Type }\end{array}$ & $\begin{array}{c}\text { Converted } \\
\text { Area }\left(10^{3} \mathrm{ha}\right)\end{array}$ & $\begin{array}{l}\text { Contribution } \\
\text { Value }\left(10^{6} \mathrm{~m}^{3}\right)\end{array}$ & $\begin{array}{c}\text { Contribution } \\
\text { Rate (\%) }\end{array}$ & $\begin{array}{c}\text { Conversion } \\
\text { Type }\end{array}$ & $\begin{array}{c}\text { Converted } \\
\text { Area }\left(10^{3} \mathrm{ha}\right)\end{array}$ & $\begin{array}{l}\text { Contribution } \\
\text { Value }\left(10^{6} \mathrm{~m}^{3}\right)\end{array}$ & $\begin{array}{c}\text { Contribution } \\
\text { Rate (\%) }\end{array}$ \\
\hline OR to $C$ & 3.70 & 6.83 & 2.06 & $\mathrm{~B}$ to $\mathrm{W}$ & 7.58 & 2.84 & 0.85 \\
\hline $\mathrm{OR}$ to $\mathrm{B}$ & 1.03 & 0.44 & 0.13 & $\mathrm{~B}$ to $\mathrm{OC}$ & 11.27 & 16.86 & 5.08 \\
\hline OR to OC & 8.16 & 13.91 & 4.19 & $\mathrm{~W}$ to $\mathrm{C}$ & 3.07 & 3.43 & 1.03 \\
\hline $\mathrm{C}$ to $\mathrm{OR}$ & 2.08 & -2.24 & -0.67 & $\mathrm{~W}$ to $\mathrm{B}$ & 2.43 & -0.74 & -0.22 \\
\hline $\mathrm{C}$ to $\mathrm{B}$ & 0.44 & -0.43 & -0.13 & $\mathrm{~W}$ to $\mathrm{OC}$ & 26.41 & 25.71 & 7.74 \\
\hline B to OR & 0.85 & 0.11 & 0.03 & OC to $\mathrm{B}$ & 8.11 & -8.25 & -2.48 \\
\hline B to C & 0.51 & 0.84 & 0.25 & OC to W & 11.69 & -10.07 & -3.03 \\
\hline Total & & & & & & 76.77 & 23.11 \\
\hline
\end{tabular}

Abbreviations: OR: oilseed rape; C: corn; B: barley; W: wheat; OC: other crops.

\section{Discussion}

\subsection{Reasons for $I W R_{c}$ Changes}

Our results show that changes in crop planting structure are the main explanation for increasing $I W R_{c}$ values within the HRB; specifically, the expansion of cultivated land has made the largest contribution to this increase. This result is important because in order to generate additional economic benefits, farmers often choose to either reclaim cultivated land or adjust the types of crops grown on existing land [45]. Our results show that a rapid expansion in cultivated land leads directly to increased crop irrigation requirements. The dominant crop in the HRB is seed corn, an agricultural product with higher economic benefits than oilseed rape, barley, or wheat. This crop, however, also consumes far more water than others; thus, increasing the planted area of corn (high water consumption) while decreasing the planted areas of barley and wheat (low water consumption) will only serve to further increase the $I W R_{c}$ in the HRB. 
Variation in $I W R_{c}$ of the same crop over time due of climate change is another factor that underlies the overall increase in these values within the HRB. Climatic factors, such as monthly mean temperature, relative humidity, wind speed, and atmospheric pressure all directly influence $E T_{o}$ and indirectly $I W R_{c}$ [54]. The data presented in this study show that temporal changes in monthly mean temperature and atmospheric pressure were more regular in the HRB than the other two factors in both 2007 and 2012 (Figure 7). Temperature exerts a positive controlling influence on $E T_{o}$; both $E T_{o}$ loss and $I W R_{c}$ are enhanced in warm compared to cold weather (Figure 7a). Besides, both relative humidity and wind speed influence vapor removal; water vapor is stored in humid air, while wind promotes the transport of water allowing more water vapour to be taken up (Figure $7 b, c$ ). Although tending to fluctuate in the same place very little over time, atmospheric pressure nevertheless determines the psychrometric constant, which is negatively correlated with both $E T_{o}$ and $I W R_{c}$ (Figure $7 \mathrm{~d}$ ). Thus, as a result of the joint impacts of crop planting structure and climate changes, $I W R_{c}$ values per unit area of oilseed rape, corn, barley, and other crops all increased between 2007 and 2012, and caused a concomitant overall increase across the whole HRB.

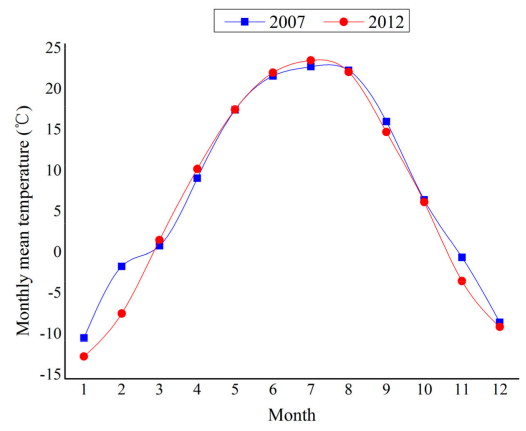

(a)

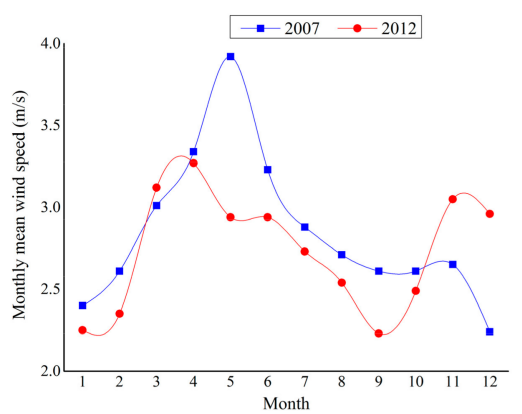

(c)

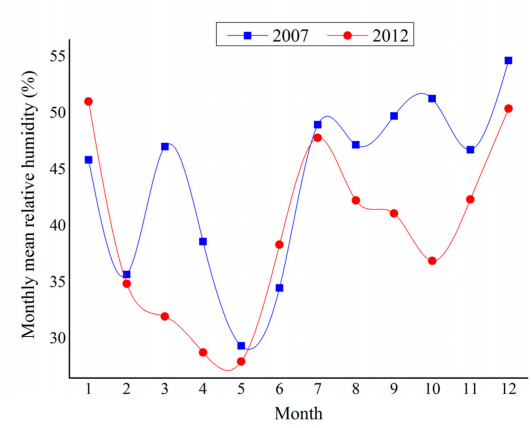

(b)

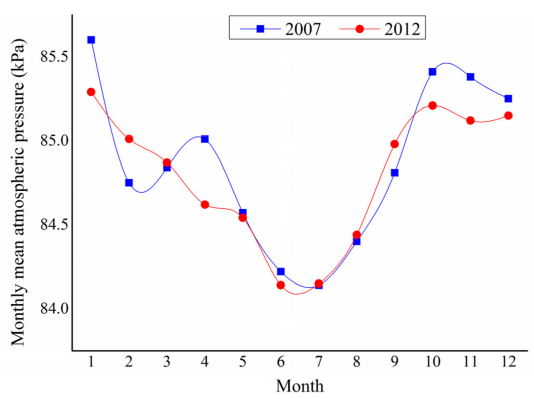

(d)

Figure 7. Monthly mean changes in climate between 2007 and 2012 in the HRB: (a) Temperature; (b) Relative humidity; (c) Wind speed; (d) Atmospheric pressure.

\subsection{Policy Implications}

Agriculture is the sector that consumes the most water in the HRB. Thus, the management of agricultural water based on sequential variation and spatial differences in $I W R_{c}$, as well as differences due to crop types, will directly determine sustainable development of both the social economy and ecological system. Data show that $I W R_{c}$ values for the same crop vary depending on growth stage; in other words, crop water requirements are highest during the middle growth stage but are lower during early and late stages. According to our field survey results, most farmers currently do not take sequential variation in $I W R_{c}$ into account when irrigating their crops. This means that both irrigation time and water supply do not correspond with the actual water requirements of crops and result in the inefficient use of irrigation water. Thus, in order to efficiently allocate and utilize available agricultural 
water, it will be necessary to adjust both irrigation times and volumes based on sequential variations in $I W R_{c}$.

The results of this study show that $I W R_{c}$ values gradually increased between 2007 and 2012 along an upstream-to-downstream transect; this means that, especially in arid areas where water is extremely scarce, $I W R_{c}$ values exceeded $1000 \mathrm{~mm}$. We therefore recommend that agricultural production in the lower reaches of the HRB should at least be reduced to preserve water and enhance ecological conservation. Unfortunately, however, the area of cultivated land in the lower reaches of the HRB expanded unreasonably between 2007 and 2012. It is therefore critical to establish a more effective mechanism of ecological compensation $[56,57]$ that enables farmers to abandon crop cultivation in the lower reaches of the HRB.

Our results show that over the time period of this study and driven by economic interests, cultivated areas of autumn crops (e.g., oilseed rape and corn) increased, while those of summer crops (e.g., barley and wheat) decreased; these changes led to a decrease in $I W R_{c}$ during May and June within the HRB and a concomitant increase in July. As the volumes of rainfall and runoff water within the HRB are largest and concentrated in June, July, and August, such a change to crop planting structures would help to ease the imbalance between water supply and demand. At the same time, however, results show that $I W R_{c}$ values for corn were significantly higher than those for the other major crops; thus, a rapid expansion in the area of cultivated corn would only serve to intensify the water supply imbalance [44]. We argue that a continuous increase in the area of cultivated corn is not feasible; rather, it is crucial to minimize the cultivation of water-intensive crops and the expansion of cultivated land, emphasizing instead the husbandry of plants that require less water $[45,58,59]$.

\subsection{The Merits and Drawbacks of this Study}

Compared with previous research on $I W R_{c}$ [31-33], we not only calculated this value for a variety of crops in this study, but also evaluated the month-by-month spatiotemporal distribution of these values. Thus, the spatiotemporal $I W R_{c}$ patterns obtained in this research, (based on crop planting structures and at a spatial resolution of $30 \mathrm{~m}$ ) are likely to aid both managers and producers to reasonably and efficiently allocate and use agricultural water in temporal and spatial sequences that coincide with differences between crop types.

However, as this study classified all crops other than oilseed rape, corn, barley, and wheat as 'other crops', it was not possible to obtain accurate growing stage and crop coefficients. We therefore estimated $I W R_{c}$ values for other crops based on the growing stages and mean $K_{c}$ values of the main crops. This is a drawback of our study as this grouping will have involved some plants with relatively low water consumption as well as fallow cultivated land; this means that our processing method, use of mean $K_{c}$ values, may have consequently overestimated the duration of each growing stage and $K_{c}$ values for other crops. This would therefore have resulted in overestimates of $I W R_{c}$ for 2007 and 2012 as well as for the whole HRB. It is also clear that, in addition to changes in crop planting structures, crop $I W R_{c}$ per unit area will also vary with time; these two factors will both affect spatiotemporal $I W R_{c}$ patterns. We did not exclude the influence of variation in crop $I W R_{c}$ per unit area in this study when analyzing the influences of crop planting structure changes, a feature of this research that will require further attention. Finally, this research is also limited by the time period we considered, just between 2007 and 2012. Our aim in future studies is to estimate the $I W R_{c}$ of the HRB over a longer time period. Furthermore, predicting future $I W R_{c}$ changes associated with crop conversion potentials [45] will also be critical for the integrated water resource management of river basins, especially in arid and semi-arid areas.

\section{Conclusions}

Water resources are intimately related to regional sustainable development and ecological security. Water wastage and inefficient use in regions subject to shortages results in serious negative economic, social, and ecological impacts. Typical for an inland river basin in an arid or semi-arid area, water 
consumption for crop irrigation in the HRB accounts for more than $80 \%$ of total regional consumption. It is therefore critical to understand the differences and variation in $I W R_{c}$ temporally, spatially, and in terms of different crop types. We used the spatiotemporal distribution of crop planting structures to estimate spatiotemporal $I W R_{c}$ values for 2007 and 2012 in the HRB. To do this, we used the FAO Penman-Monteith method, revealed the characteristics of spatiotemporal variation in $I W R_{c}$, and analyzed the resultant impacts of crop planting structure changes.

The results of this study show that the $I W R_{c}$ within the HRB varied between zero and $1250 \mathrm{~mm}$ and that the amplitude of variation increased along an upstream-to-downstream transect. Values for $I W R_{c}$ in the lower reaches of the HRB were as high as $1000 \mathrm{~mm}$, which suggests that agricultural production in this region should be minimized in order to save water for ecological conservation. Data show that the annual mean $I W R_{c}$ of the HRB increased from $339.95 \mathrm{~mm}$ in 2007 to $370.11 \mathrm{~mm}$ in 2012; at the same time, monthly mean $I W R_{c}$ initially increased before gradually decreasing with the highest values each year seen in June. Between 2007 and 2012, $I W R_{c}$ values in May and June decreased by 8.14 and $11.67 \mathrm{~mm}$, respectively, while those for July increased by $5.75 \mathrm{~mm}$. As the ER in May and June is less than that in July, this change in $I W R_{c}$ might be useful to help alleviate the imbalance between water supply and demand for irrigation. In terms of crop types, $I W R_{c}$ values for corn were significantly higher than those for oilseed rape, barley, and wheat; nevertheless, mean $I W R_{c}$ values of oilseed rape, corn, barley, and other crops increased, respectively, from 208.43, 349.35, 229.26, and $352.85 \mathrm{~mm}$ in 2007 to $241.81,393.10,251.17$, and $378.86 \mathrm{~mm}$ in 2012. At the same time, the mean IWRc for wheat decreased from $281.53 \mathrm{~mm}$ in 2007 to $266.69 \mathrm{~mm}$ in 2012. Therefore, in order to efficiently manage and utilize agricultural water, we argue that it is necessary to adjust both irrigation times and amounts in different areas depending on the differences and characteristics of $I W R_{c}$ variation temporally, spatially, and by crop types.

To increase their economic benefits, farmers have tended to adjust planting structures to favor more profitable crops that also need more water (e.g., corn) or reclaim more cropland. Our data show that planting structure changes took place within the HRB between 2007 and 2012 to increase areas of corn and oilseed rape, while simultaneously decreasing areas of planted barley and wheat and expanding the cultivated land area. These changes resulted in an $I W R_{c}$ increase from $2360.42 \times 10^{6} \mathrm{~m}^{3}$ in 2007 to $2692.58 \times 10^{6} \mathrm{~m}^{3}$ in 2012 , corresponding to an increase by $332.16 \times 10^{6} \mathrm{~m}^{3}(14.07 \%)$. Data show that $23.11 \%\left(76.77 \times 10^{6} \mathrm{~m}^{3}\right)$ of this change can be explained by crop type transfers, and that the remaining $76.89 \%\left(255.39 \times 10^{6} \mathrm{~m}^{3}\right)$ was caused by the rapid expansion of cultivated land. Although farmers obtained economic benefits in the short term, this approach was not conducive to maintaining the sustainable development and ecological security of the HRB. We recommend that, in future, the cultivation of water-demanding crops and the expansion of cultivated land should be kept to a minimum.

The analysis of spatiotemporal changes in $I W R_{c}$ presented in this paper will enable both managers and producers to develop more efficient irrigation strategies that those presently available in the absence of these data. Future research is nevertheless essential for the integrated management of water resources in river basins. Studies should include estimating large scale spatial (e.g., at the national or global scale) $I W R_{c}$ over longer time periods, predicting future $I W R_{c}$ changes associated with crop conversion potential, and the multi-objective optimization of water resources between agriculture and other sectors in light of different scenarios for development. All of these directions are essential if we are to guarantee regional and global sustainability.

Acknowledgments: The research was supported by the National Natural Science Foundation of China (Grant Nos. 91325302, 91325303 and 41671177).

Author Contributions: Wei Song designed the research. Yaqun Liu processed the data, developed the methodology, performed the research, and wrote the manuscript. Wei Song reviewed the paper and supported the analysis of the results. Wei Song and Xiangzheng Deng supervised the research and contributed with valuable discussions and scientific advice.

Conflicts of Interest: The authors declare no conflict of interest. 


\section{References}

1. Xu, Q.; Song, W.; Zhang, Y. Forecast and optimal allocation of production, living and ecology water consumption in Zhangye, China. Phys. Chem. Earth 2016, 96, 16-25. [CrossRef]

2. Li, Z.H.; Deng, X.Z.; Wu, F.; Hasan, S.S. Scenario analysis for water resources in response to land use change in the middle and upper reaches of the Heihe River Basin. Sustainability 2015, 7, 3086-3108. [CrossRef]

3. Bekchanov, M.; Karimov, A.; Lamers, J.P.A. Impact of water availability on land and water productivity: A temporal and spatial analysis of the case study region Khorezm, Uzbekistan. Water 2010, 2, 668-684. [CrossRef]

4. Mancosu, N.; Snyder, R.L.; Kyriakakis, G.; Spano, D. Water scarcity and future challenges for food production. Water 2015, 7, 975-992. [CrossRef]

5. Vorosmarty, C.J.; Green, P.; Salisbury, J.; Lammers, R.B. Global water resources: Vulnerability from climate change and population growth. Science 2000, 289, 284-288. [CrossRef] [PubMed]

6. Wallace, J.S. Increasing agricultural water use efficiency to meet future food production. Agric. Ecosyst. Environ. 2000, 82, 105-119. [CrossRef]

7. Song, W.; Pijanowski, B.C. The effects of China's cultivated land balance program on potential land productivity at a national scale. Appl. Geogr. 2014, 46, 158-170. [CrossRef]

8. Lee, J.L.; Huang, W.C. Impact of climate change on the irrigation water requirement in northern Taiwan. Water 2014, 6, 3339-3361. [CrossRef]

9. Deng, X.Z.; Shi, Q.L.; Zhang, Q.; Shi, C.C.; Yin, F. Impacts of land use and land cover changes on surface energy and water balance in the Heihe River Basin of China, 2000-2010. Phys. Chem. Earth 2015, 79-82, 2-10. [CrossRef]

10. Song, W.; Pijanowski, B.C.; Tayyebi, A. Urban expansion and its consumption of high-quality farmland in Beijing, China. Ecol. Indic. 2015, 54, 60-70. [CrossRef]

11. Yu, B.H.; Song, W.; Lang, Y.Q. Spatial patterns and driving forces of greenhouse land change in Shouguang City, China. Sustainability 2017, 9, 359. [CrossRef]

12. Teshager, A.D.; Gassman, P.W.; Schoof, J.T.; Secchi, S. Assessment of impacts of agricultural and climate change scenarios on watershed water quantity and quality, and crop production. Hydrol. Earth Syst. Sci. 2016, 20, 3325-3342. [CrossRef]

13. Du, Y.H.; Berndtsson, R.; An, D.; Zhang, L.; Hao, Z.C.; Yuan, F.F. Hydrologic response of climate change in the source region of the Yangtze River, based on water balance analysis. Water 2017, 9, 115. [CrossRef]

14. Ning, T.T.; Li, Z.; Liu, W.Z. Vegetation dynamics and climate seasonality jointly control the interannual catchment water balance in the Loess Plateau under the Budyko framework. Hydrol. Earth Syst. Sci. 2017, 21, 1515-1526. [CrossRef]

15. Fan, L.; Lu, C.H.; Yang, B.; Chen, Z. Long-term trends of precipitation in the North China Plain. J. Geogr. Sci. 2012, 22, 989-1001. [CrossRef]

16. Shi, Q.L.; Chen, S.Y.; Shi, C.C.; Wang, Z.; Deng, X.Z. The impact of industrial transformation on water use efficiency in northwest region of China. Sustainability 2015, 7, 56-74. [CrossRef]

17. Deng, X.P.; Shan, L.; Zhang, H.P.; Turner, N.C. Improving agricultural water use efficiency in arid and semiarid areas of China. Agric. Water Manag. 2006, 80, 23-40. [CrossRef]

18. De Wit, M.; Stankiewicz, J. Changes in surface water supply across Africa with predicted climate change. Science 2006, 311, 1917-1921. [CrossRef] [PubMed]

19. Jenerette, G.D.; Larsen, L. A global perspective on changing sustainable urban water supplies. Glob. Planet Chang. 2006, 50, 202-211. [CrossRef]

20. Song, W.; Deng, X.Z. Land-use/land-cover change and ecosystem service provision in China. Sci. Total Environ. 2017, 576, 705-719. [CrossRef] [PubMed]

21. Tao, F.L.; Yokozawa, M.; Hayashi, Y.; Lin, E.D. A perspective on water resources in China: Interactions between climate change and soil degradation. Clim. Chang. 2005, 68, 169-197. [CrossRef]

22. Qi, S.Z.; Luo, F. Water environmental degradation of the Heihe River Basin in arid northwestern China. Environ. Monit. Assess. 2005, 108, 205-215. [CrossRef] [PubMed]

23. Yang, F.B.; Lu, C.H. Spatiotemporal variation and trends in rainfall erosivity in China's dryland region during 1961-2012. Catena 2015, 133, 362-372. [CrossRef] 
24. Vorosmarty, C.J.; Willmott, C.J.; Choudhury, B.J.; Schloss, A.L.; Stearns, T.K.; Robeson, S.M.; Dorman, T.J. Analyzing the discharge regime of a large tropical river through remote sensing, ground-based climatic data, and modeling. Water Resour. Res. 1996, 32, 3137-3150. [CrossRef]

25. Uniyal, B.; Jha, M.; Verma, A. Assessing climate change impact on water balance components of a river basin using SWAT model. Water Resour. Manag. 2015, 29, 4767-4785. [CrossRef]

26. Van Beusekom, A.E.; Viger, R.J. A glacier runoff extension to the Precipitation Runoff Modeling System. J. Geophys. Res. 2016, 121, 2001-2021. [CrossRef]

27. Kavvas, M.L.; Chen, Z.Q.; Tan, L.; Soong, S.T.; Terakawa, A.; Yoshitani, J.; Fukami, K. A regional-scale land surface parameterization based on areally-meand hydrological conservation equations. Hydrol. Sci. J. 1998, 43, 611-631. [CrossRef]

28. Zhou, Q.; Wu, F.; Zhang, Q. Is irrigation water price an effective leverage for water management? An empirical study in the middle reaches of the Heihe River basin. Phys. Chem. Earth 2015, 89-90, 25-32. [CrossRef]

29. Ge, L.Q.; Li, S.M.; Xie, G.D.; Cheng, Y.P.; Ni, Z.S. The population carrying capacity of waters ecosystem in China. J. Resour. Ecol. 2016, 7, 21-27.

30. Ye, Q.; Yang, X.G.; Dai, S.W.; Chen, G.S.; Li, Y.; Zhanga, C.X. Effects of climate change on suitable rice cropping areas, cropping systems and crop water requirements in southern China. Agric. Water Manag. 2015, 159, 35-44. [CrossRef]

31. Shrestha, L.; Shrestha, N.K. Assessment of climate change impact on crop yield and irrigation water requirement of two major cereal crops (rice and wheat) in Bhaktapur district, Nepal. J. Water Clim. Chang. 2017, 8, 320-335. [CrossRef]

32. Rotich, S.C.; Mulungu, D.M.M. Adaptation to climate change impacts on crop water requirements in Kikafu catchment, Tanzania. J. Water Clim. Chang. 2017, 8, 274-292. [CrossRef]

33. Luo, X.P.; Xia, J.; Yang, H. Modeling water requirements of major crops and their responses to climate change in the North China Plain. Environ. Earth Sci. 2015, 74, 3531-3541. [CrossRef]

34. Bocchiola, D. Impact of potential climate change on crop yield and water footprint of rice in the Po valley of Italy. Agric. Syst. 2015, 139, 223-237. [CrossRef]

35. Shen, Y.J.; Li, S.; Chen, Y.N.; Qi, Y.Q.; Zhang, S.W. Estimation of regional irrigation water requirement and water supply risk in the arid region of Northwestern China 1989-2010. Agric. Water Manag. 2013, 128, 55-64. [CrossRef]

36. Yang, Y.M.; Liu, D.L.; Anwar, M.R.; O’Leary, G.; Macadam, I.; Yang, Y.H. Water use efficiency and crop water balance of rainfed wheat in a semi-arid environment: Sensitivity of future changes to projected climate changes and soil type. Theor. Appl. Climatol. 2016, 123, 565-579. [CrossRef]

37. Lu, C.H.; Fan, L. Winter wheat yield potentials and yield gaps in the North China Plain. Field Crop. Res. 2013, 143, 98-105. [CrossRef]

38. Jin, T.; Qing, X.Y.; Huang, L.Y. Changes in grain production and the optimal spatial allocation of water resources in China. J. Resour. Ecol. 2016, 7, 28-35.

39. Lang, Y.Q.; Song, W.; Zhang, Y. Responses of the water-yield ecosystem service to climate and land use change in Sancha River Basin, China. Phys. Chem. Earth 2017. [CrossRef]

40. Deng, X.Z.; Singh, R.B.; Liu, J.G.; Guneralp, B. Water productivity and integrated water resources management. Phys. Chem. Earth 2016, 96, 1. [CrossRef]

41. Deng, X.Z.; Singh, R.B.; Liu, J.G.; Guneralp, B. Water use efficiency and integrated water resource management for river basin. Phys. Chem. Earth 2015, 89-90, 1-2.

42. Mamitimin, Y.; Feike, T.; Doluschitz, R. Bayesian network modeling to improve water pricing practices in northwest China. Water 2015, 7, 5617-5637. [CrossRef]

43. Deng, X.Z.; Zhao, C.H. Identification of water scarcity and providing solutions for adapting to climate changes in the Heihe River Basin of China. Adv. Meteorol. 2015. [CrossRef]

44. Liu, Y.Q.; Song, W.; Mu, F.Y. Changes in ecosystem services associated with planting structures of cropland: A case study in Minle County in China. Phys. Chem. Earth 2017. [CrossRef]

45. Liu, Y.Q.; Song, W.; Deng, X.Z. Changes in crop type distribution in Zhangye City of the Heihe River Basin, China. Appl. Geogr. 2016, 76, 22-36. [CrossRef]

46. Song, W.; Zhang, Y. Expansion of agricultural oasis in the Heihe River Basin of China: Patterns, reasons and policy implications. Phys. Chem. Earth 2015, 89-90, 46-55. 
47. Fu, P.D.; Rich, P.M. A geometric solar radiation model with applications in agriculture and forestry. Comput. Electron. Agric. 2002, 37, 25-35. [CrossRef]

48. Huete, A.; Didan, K.; Miura, T.; Rodriguez, E.P.; Gao, X.; Ferreira, L.G. Overview of the radiometric and biophysical performance of the MODIS vegetation indices. Remote Sens. Environ. 2002, 83, 195-213. [CrossRef]

49. Gao, B.C. NDWI-A normalized difference water index for remote sensing of vegetation liquid water from space. Remote Sens. Environ. 1996, 58, 257-266. [CrossRef]

50. Tayyebi, A.; Pijanowski, B.C. Modeling multiple land use changes using ANN, CART and MARS: Comparing tradeoffs in goodness of fit and explanatory power of data mining tools. Int. J. Appl. Earth Obs. Geoinf. 2014, 28, 102-116. [CrossRef]

51. Hutchinson, M.F. Interpolation of rainfall data with thin plate smoothing splines: I two dimensional smoothing of data with short range correlation. J. Geogr. Inf. Decis. Anal. 1998, 2, 152-167.

52. Nagarajan, N.; Poongothai, S. Spatial mapping of runoff from a watershed using SCS-CN method with remote sensing and GIS. J. Hydrol. Eng. 2012, 17, 1268-1277. [CrossRef]

53. Penman, H.L. Natural evaporation from open water, bare soil and grass. Proc. R. Soc. Lond. Ser. A 1948, 193, 120-145. [CrossRef]

54. Allan, R.G.; Pereira, L.S.; Raes, D.; Smith, M. Crop Evapotranspiration: Guidelines for Computing Crop Water Requirements; FAO Irrigation and Drainage Paper No. 56; FAO: Rome, Italy, 2005; p. 56.

55. Smith, P.C.; Calanca, P.; Fuhrer, J. A simple scheme for modeling irrigation water requirements at the regional scale applied to an alpine river catchment. Water 2012, 4, 869-886. [CrossRef]

56. Han, Z.; Song, W.; Deng, X.Z. Progress in the research on benefit-sharing and ecological compensation mechanisms for transboundary rivers. J. Resour. Ecol. 2017, 8, 129-140.

57. Jiang, Q.O.; Deng, X.Z.; Zhan, J.Y.; Yan, H.M. Impacts of economic development on ecosystem risk in the Yellow River Delta. Procedia Environ. Sci. 2011, 5, 208-218. [CrossRef]

58. Davis, K.F.; Seveso, A.; Rulli, M.C.; D'Odorico, P. Water savings of crop redistribution in the United States. Water 2017, 9, 83. [CrossRef]

59. Jiang, Q.O.; Deng, X.Z.; Zhan, J.Y.; He, S.J. Estimation of land production and its response to cultivated land conversion in North China Plain. Chin. Geogr. Sci. 2011, 21, 685-694. [CrossRef] 